\title{
3D GEOSTATISTICAL INTERPOLATION AND GEOLOGICAL INTERPRETATION OF PALEO-GROUNDWATER RISE IN THE HOLOCENE COASTAL PRISM IN THE NETHERLANDS
}

\author{
KIM M. COHEN \\ Centre for Geo-ecological Research (ICG), Dept. of Physical Geography, Faculty of Geosciences, \\ Utrecht University, P.O. Box 80115, 3508 TC Utrecht, The Netherlands \\ e-mail:kcohen@geo.uu.nl
}

\begin{abstract}
Авsтract: Coastal-prism sediments record rising local water levels, forced by sea-level rise. Sea-level rise is the primary driving factor, but the anatomy of the coastal prism is a result of a complex interplay of sea level, subsidence, and upstream controls (essentially sediment load). The sedimentary architecture of a coastal prism is linked to paleo-groundwater rise. Groundwater rise is quantified for the entire Rhine-Meuse delta (extending $120 \mathrm{~km}$ inland, $60 \mathrm{~km}$ wide) between an $11.0 \mathrm{kyr}$ BP groundwater lowstand and the present highstand, dating series of organic markers (peats) of paleo-groundwater levels at compaction-free locations. The accumulated dataset of paleo-groundwater-level markers (> 300 index points) has a dense spatial and temporal coverage and a predictive quality that enables geostatistical analysis. The combination of this dataset and a carefully designed interpolation method (a form of 3D kriging) reveals the interplay between upstream (climate, discharge) and downstream (sea level, tides) controls on gradients of groundwater level and patterns of groundwater rise. Regional effects due to local controls (differential subsidence, groundwater flow) are also identified.

It is shown that backfilling of the paleovalley continues into the late Holocene, when eustatic rise had ceased, while at the same time the delta is prograding in the backbarrier area. The results corroborate earlier results regarding differential subsidence and postglacial enhanced subsidence rates (relative to long-term background rates) in the delta. Moreover, the 3-D geostatistical interpolation opens possibilities to test and further develop process-based models for deltaic deposition.
\end{abstract}

\section{INTRODUCTION}

Holocene coastal prisms (cf. Posamentier et al., 1992) have built up all over the world in response to global deglaciation and resulting sea-level rise. Modern coastal prisms in general have a base that dates to the beginning of the middle Holocene $(\sim 8 \mathrm{cal}$ kyr BP; Stanley and Warne, 1994). Their sedimentary record shows rapid aggradation during the middle Holocene, decreasing markedly in the late Holocene. Coastal prisms are usually underlain by Late-glacial to early Holocene fluvial deposits of paleovalleys that had formed during the preceding lowstand (Marine Oxygen Isotope Stages 4 to 2: OIS 4-2).

Paleo-equivalents of the present-day depositional environments are recorded in the coastal prism. Quantitative reconstruction of paleo-groundwater surfaces allows identification of these paleo-equivalents regionally, and may reflect shifts in dominance of interplaying upstream and downstream controls during coastal-prism buildup. The construction of a 4D dataset and "prediction" of paleo-groundwater levels (groundwatertable elevations) by interpolation (rather than modeling) serves to identify and quantify the interplay between the various controls. The aim of this work is (1) to interpret the record of paleo-groundwater rise in the Rhine-Meuse coastal prism and to identify controlling factors in the deltaic sedimentary record; by (2) presenting a methodology for geostatistical interpolation of a database of $>300$ groundwater-level index points now available.

\section{Geological Setting: Sedimentation during Groundwater-Level Rise}

The Rhine-Meuse coastal prism (Fig. 1) consists of coastal barrier deposits and backbarrier deltaic deposits including estuarine and fluvial sediments and floodbasin peats. Sea-level rise, increase of discharge, and changing groundwater hydrology raised the groundwater level. This provided the accommodation space (accumulation space sensu Blum and Törnqvist, 2000) for the coastal prism. Other controls, such as tides, local subsidence, and fluvial discharge, also affected the deltaic ground water table, as did the antecedent topographic and hydrologic setting. All these factors also control the internal sedimentary architecture of the coastal prism.

Under conditions of sea-level rise, peat formed extensively in middle Holocene floodbasins. Peat from locations all over the study area has yielded radiocarbon dates ranging from 9.5 to 3.0 cal kyr BP. Peaty sequences from distal floodbasins provide excellent organic markers for dating the start of peat formation and thus for pinpointing paleo-groundwater levels (water-table elevations). The geological setting allows reconstruction of ground water rise and floodbasin aggradation, by dating series of basal peat samples at increasing elevations at sites free of compaction (e.g., along flanks of buried dunes, Fig. 2; Jelgersma, 1961; van de Plassche, 1982; van Dijk et al., 1991).

In the present highstand situation, longitudinal gradients in groundwater levels over the lower, central, and upper delta reaches are graded to the late Holocene highstand sea level (Fig. 1). Sea level is the dominant control on paleo-groundwater levels in the coastal prism, in particular in the most downstream parts. From delta apex to coast, the concave surface reflects a relatively decreasing influence of upstream controls (discharge and sediment load, which impose a valley gradient), relative to an increasing influence of downstream controls (sea level and tidal amplitude, which decrease the gradient). Near the coast, in the lower delta, marine controls are dominant. Farther inland, in the central and upper delta, downstream controls are less dominant and interplay with upstream controls is obvious. Here, floodbasin aggradation forced by relative sea-level rise occurred (Törnqvist, 1993; Berendsen and Stouthamer, 2001), but the sedimentation is 


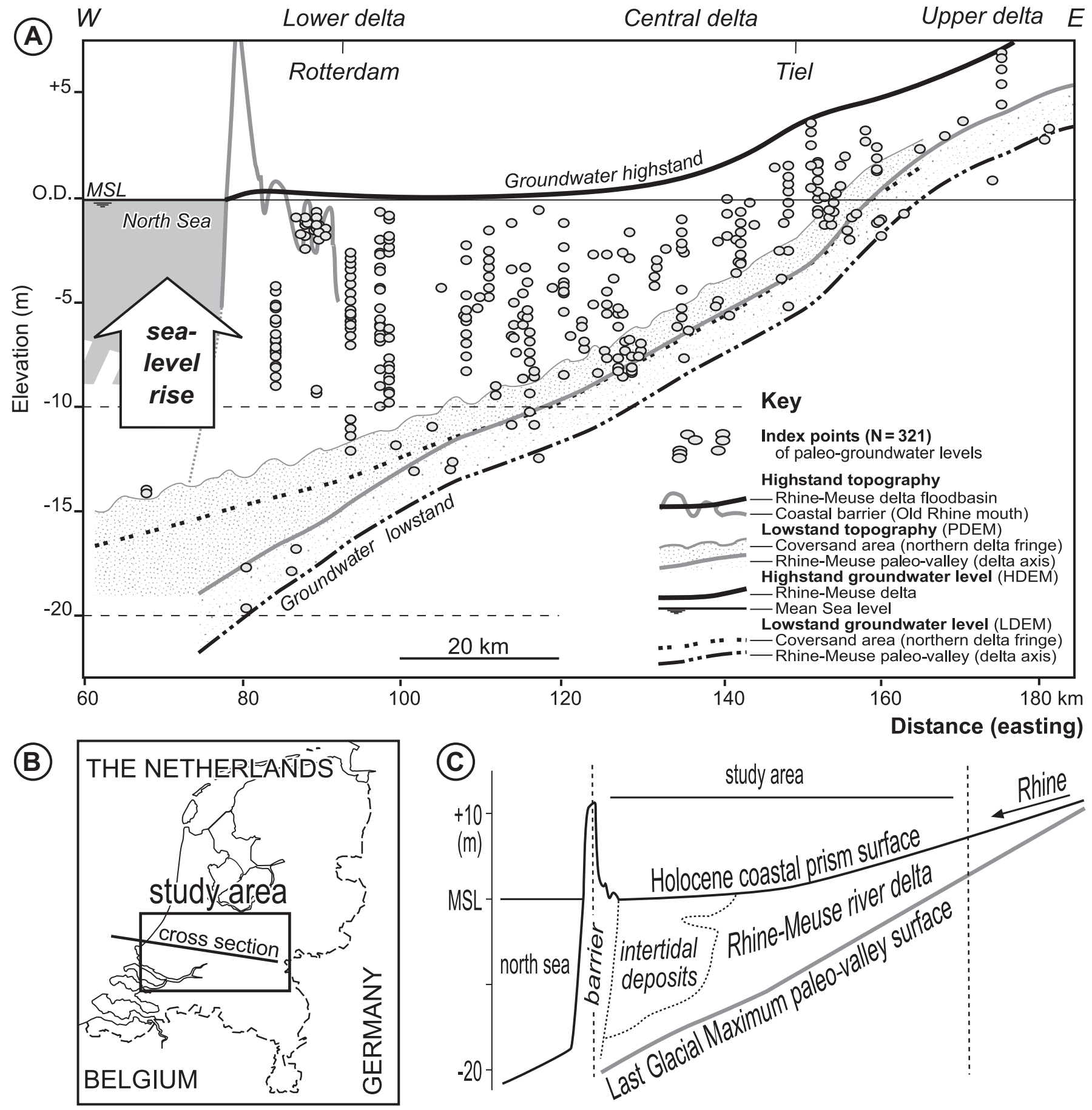

FIG. 1.-Holocene Rhine-Meuse delta coastal prism. A) Section along the central axis of the delta. Index points $\left({ }^{14} \mathrm{C}\right.$-dated basal peat; see text) indicate paleo-groundwater levels and document the rise of groundwater level between an initial lowstand (lowest groundwater level) towards the present highstand (highest groundwater level). Coastal-prism deposits backfilled the paleovalley and reach their maximum thickness along the central delta axis. Outside this paleovalley the coastal prism is less thick and overlies Late-glacial coversands. B) Location of study area. C) Main sedimentary settings in the coastal prism.

strictly fluvial (fresh-water to brackish-water peat; no tidal signal in the sediments; channel belts of fluvial style).

During sea-level lowstand (e.g., OIS 2) a different state of control-interplay existed. In the Late-glacial, groundwater levels at the present river mouth were $\sim 25$ m lower than at present, but they never dropped far below the topographic surface (de Vries, 1974; van de Plassche, 1982). The groundwater table remained within a few meters below the average surface of the paleovalley and direct surroundings. The term "groundwater lowstand" is introduced for the lowest level of the groundwater table before 


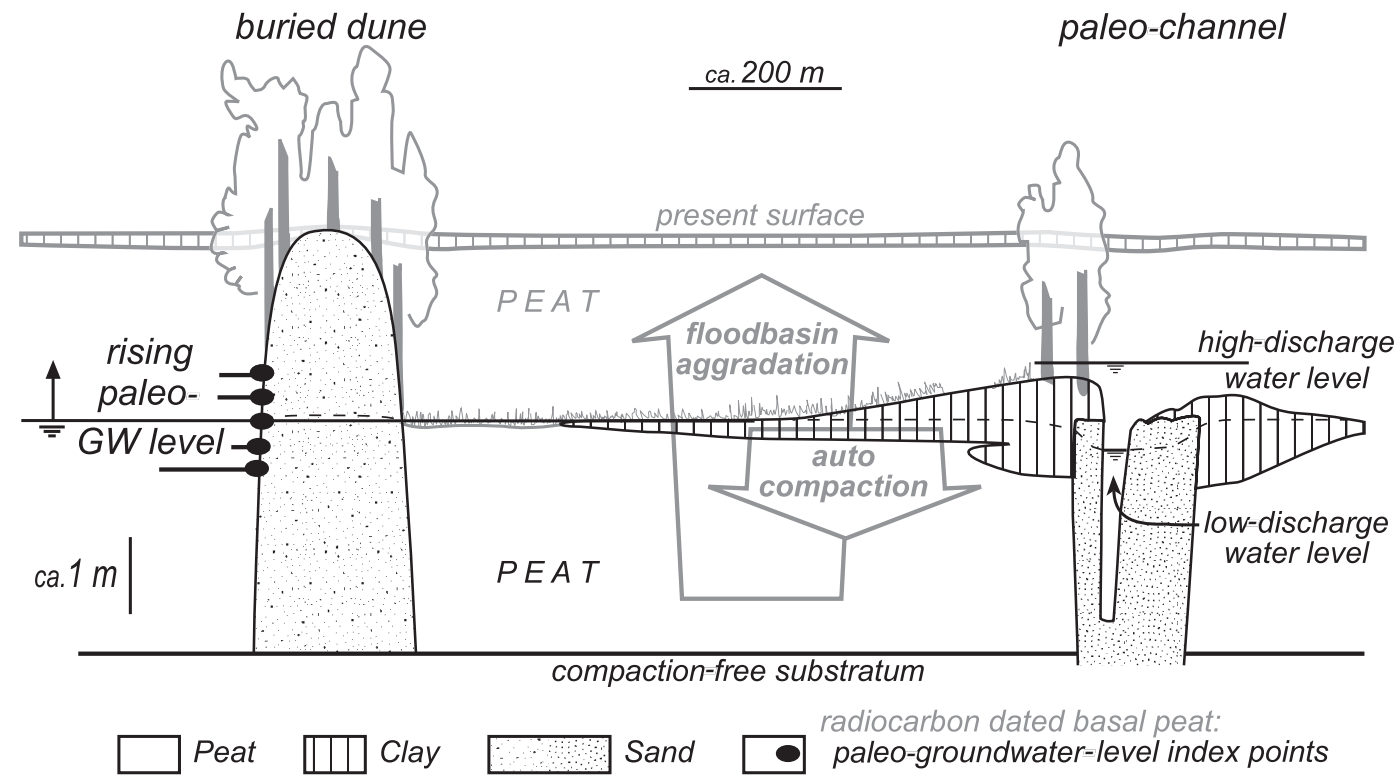

FIG. 2.-Groundwater level as local base level for floodbasin sedimentation. Schematic cross section relating distal floodbasin aggradation with the sedimentary record of the floodbasin proximal to deltaic distributaries. Series of radiocarbon-dated basal peat sampled at eolian dune sites located in distal floodbasins document groundwater rise.

the onset of coastal-prism buildup. In the groundwater-lowstand situation, the dominant controls were discharge (both fluvial and groundwater flow) and the antecedent topography of the paleovalley. Prior to coastal-prism buildup, sea level was not a direct control, therefore the timing of the groundwater lowstand does not necessarily coincide with a sea-level lowstand.

The extensive occurrence of middle Holocene floodbasin peat indicates that insufficient sediment was available to fill the entire accommodation. In this situation paleo-groundwater levels had a direct relation with sedimentary processes in the contemporary delta. Overbank sedimentation was graded to the water level in the distal floodbasins (Fig. 2) because middle Holocene creation of accommodation space exceeded sedimentation. In the late Holocene, floodbasin peat did not form extensively, indicating that sediment supply was sufficient to fill the entire accommodation space created by downstream sea-level rise. Particularly in the upstream part of the delta, sedimentation may have regionally raised floodbasin topography and thereby groundwater tables. In that situation, groundwater levels were influenced by overbank sedimentation. However, in most parts of the coastal prism, late Holocene overbank deposits are underlain by thick middle Holocene peat-rich sequences. There, compaction of underlying peat acts as an internal mechanism that maintains a situation of overbank sedimentation graded to the floodbasin groundwater table. In summary, groundwater levels as recorded by basal peat are interpreted to have controlled deltaic sedimentation. Therefore, groundwater-level rise is a key factor in explaining spatio-temporal trends observed (e.g., Törnqvist, 1993) in the sedimentary architecture of the coastal prism.

\section{Quantitative Analysis of Holocene Groundwater-Level Rise}

The age of peat at the base of Holocene floodbasin sequences have been dated extensively in the Rhine-Meuse delta. At locations where such so-called basal peat has buried a former surface of sandy deposits (e.g., Fig. 2) it formed free of autocompaction (cf. Allen, 1999) and therefore is an excellent recorder of Holocene deltaic paleo-groundwater levels. Each basal peat sample represents a paleo-groundwater table, to which peat formation was graded at the time of its formation. The paleo-groundwater level $(Z)$ follows from the sample elevation, and its age $(A)$ follows from the radiocarbon date. The dated basal centimeters of peat record a mean water level, averaged over several decades (50-100 $\mathrm{yr}$, comparable to typical ${ }^{14} \mathrm{C}$ date measurement errors). Seasonal variation (lower summer levels due to evaporation and lower discharge, higher levels in the flooding season) would have occurred and influenced the vegetation that formed the peat, but its effects average out over the time that peat takes to form and therefore is not recorded as such in the record of basal peat. In tidally influenced floodbasins, the reconstructed paleo-groundwater levels approximate mean daily high water levels rather than mean water levels (van de Plassche, 1982; van de Plassche and Roep, 1989). Interpretation of series of samples from local sites (Fig. 3) has allowed identification of controls on the basis of the rate of groundwater rise (e.g., Jelgersma, 1961; van de Plassche, 1982, 1995; van Dijk et al., 1991; Kiden, 1995; Törnqvist et al., 1998). Locally, during short periods of time, groundwater levels may have been lowered, for example because of changes in floodbasin size and local tidal amplitude (van de Plassche, 1982, 1995). Regionally, however, and averaged over periods longer than centuries, relative groundwater rise is thought to have been continuous since its onset in the early Holocene.

In the central delta, peat formation regionally occurred above contemporary sea levels, and paleo-groundwater levels have a longitudinal gradient comparable to the present surface, which is related to the river gradients (van Dijk et al., 1991). In the lower delta, there is virtually no gradient and paleo-groundwater levels are close to sea level, i.e., between mean sea level (MSL) and mean high water level (van de Plassche, 1995). Over time, the gradient of paleo-groundwater levels has decreased (van Dijk et al., 1991), hence the tilted-wedge shape of the coastal prism (Fig. 1). Longitudinal slope differences over the 
Holocene are greatest in the lower delta, where the lowstand valley gradient at $20 \mathrm{~m}$ below OD (ordnance datum $\approx$ present MSL) is approximately $0.2 \mathrm{~m} / \mathrm{km}$, whereas the gradient of the present deltaic surface approaches zero $(<0.05 \mathrm{~m} / \mathrm{km})$. Apart from the longitudinal gradient, lateral (tangential) gradients also exist in the paleo-groundwater tables. These are explained by groundwater flow from the areas that border the paleovalley to the north and south. In these areas periglacial aeolian sand sheets ("coversands") had accumulated earlier, most recently during the last glacial maximum (OIS 2). In the groundwaterlowstand situation, these areas had higher groundwater tables than the valley itself (van de Plassche, 1982) and its Late-glacial and early Holocene groundwater flow partly discharged into the valley (both as channel flow and as subsurface flow, i.e., base flow; de Vries, 1974). The effects of longitudinal and lateral gradients appear in age-depth plots: central-delta and deltarim sites plot above near-coastal sites, and consequently, curves of inland groundwater rise plot above the MSL curve (Fig. 3).

As the number of peat ages accumulated and more advanced sample preparation and dating techniques became available, resolution and areal coverage increased. This has made it possible to assess this dataset delta-wide (this paper). The full dataset was quantitatively integrated to map and analyze longitudinal and lateral gradients of paleo-groundwater surfaces over the entire delta, by performing a geostatistical interpolation. To be in balance with the geological aim that it serves, the interpolation followed several principles: (1) Embedded in the design are general concepts derived from the geological setting, e.g., groundwater rose continuously from lowstand to the present highstand and continues to rise today. (2) Availability of data dictates the applicable techniques. The availability of data itself is dictated by the geological setting. Hence the nature of the geological record also determines the applicability of geostatistical techniques. (3)Separate identification of general trends and superimposed regionallocal variation is needed to allow interpretation of control interplay. The applied geostatistical method is specifically designed to break the record down into its various geological components.

\section{INPUT DATA}

Geostatistical techniques demand critically evaluated quality data as an input to avoid pitfalls of overinterpretation. The same holds for interpreted geological data such as lithological descriptions, palynological analyses, and dating results. Because this study is a geostatistical application to Late Quaternary geological proxy data from multiple sources and various publications, critical evaluation becomes even more important. Therefore data used in the interpolation and the input data's predictive quality for paleo-groundwater-level reconstruction is discussed below. The input data comprise (1) index points documenting the temporal evolution of Holocene groundwater levels at different sites, and (2) the lower and upper groundwater surfaces that envelop this data set.

\section{Dataset of Paleo-Groundwater-Level Index Points}

Over 300 groundwater-level index points (Fig. 3), mainly from dated basal peats (44 newly collected, the rest previously published or published as "in prep." in Berendsen and Stouthamer, 2001), were used in this study. For all index points, original site and sample descriptions and interpretations and considerations and/or remarks from follow-up publications were evaluated. A database was constructed that contains: site name and number, original reference, coordinates, ${ }^{14} \mathrm{C}$-dating result, description of the dated material (mostly basal peat, occasionally paleosol $\mathrm{A}$ horizons for sites that lack basal peat), description of its substratum (Late Weichselian coversand, Younger Dryas eolian dune sand, Late Weichselian fluvial sandy loam) and a label grouping sites by locations (regionally) in the delta (Fig. 3). The dataset can be downloaded from http://www.geog.uu.nl/fg/ palaeogeography.

Each index point is defined by its spatial coordinates $X Y$ (Dutch coordinate system, error $\pm 5 \mathrm{~m}$ ), by sample elevation $Z$ (paleowater-level elevation relative to ordnance datum $\approx$ present MSL) and by its age $A$ (radiocarbon dating result). Errors in $Z$ are typically $0.10-0.50 \mathrm{~m}$ (Törnqvist et al., 1998) and are related to the water-depth ranges of the vegetation that formed the peat. Most dates ( $>80 \%$ ) are from Alnus peat, and have errors in Z of 0.15$0.30 \mathrm{~m}$. Sampling errors in $Z$ (resulting from leveling surface elevation and measuring depth below surface while coring) are small $(<0.05 \mathrm{~m})$. Dates (in ${ }^{14} \mathrm{C}$ yr BP) were calibrated to calendaryear ages (cal yr BP), using a standard dataset (INTCAL98 of Stuiver et al., 1998) and software (OxCal; Bronk-Ramsey, 1998). Standard deviations are typically 80-200 cal yr and depend on dating technique (AMS dating of selected macrofossils vs. conventional dating of bulk samples) and position on the calibration curve. About half of the index points are from sites along the WE delta axis, where Late-glacial (Younger Dryas) eolian dunes are buried by peat. Here, series were sampled at high vertical resolution (typically 3-5 dates per meter of elevation increase). At these densely sampled sites, the relative stratigraphic positions of successive dates (formulated in OxCal's Chronological Query Language; Bronk-Ramsey, 1998) were taken into account while calibrating radiocarbon dates, to further narrow the age ranges of individual index points. Curves of groundwater rise can be drawn (visually or mathematically) through the index points (e.g., Fig. 3). The MSL curve is at a slightly lower level than the lowest index points, because peat always forms above sea level.

\section{Dataset Envelope, Bounding Surfaces}

The index points of paleo-groundwater levels form a cloud of data that is bounded by an upper surface (i.e., the deltaic highstand groundwater level) and a lower surface (i.e., a Late-glacial or earliest Holocene groundwater lowstand). The envelope approximates the thickness of Holocene delta deposits $(D)$. The 3D shape of the envelope is determined from independent data (topography, palynology) that have no direct relation to the index points. For the highstand situation, average groundwater levels are at (or very close to) the topographic surface in the floodbasins. For the groundwater-lowstand situation, average groundwater levels were within 2 meters below Late-glacial topographic elevation for both the paleovalley and the surrounding coversand area (Fig. 1). This is based on hydrological considerations (de Vries, 1974), supported by lithological and pedogenic evidence (van de Plassche, 1982; Cohen, 2003). For the highstand the topographic elevation is known from geodetic surveys, and for the lowstand, from boreholes. The relation between topography and groundwater levels was specified and the groundwater lowstand and highstand surfaces were calculated using Geographic Information System (GIS) techniques (see Appendix for details). Subsequently, the groundwater rise that is documented by the data cloud of index points in between the bounding lowstand and highstand extremes was interpolated.

\section{Paleo-Groundwater-Level Data: Predictive Quality}

The index-point dataset shows the major part of the coastal prism accommodated during the middle Holocene, under conditions of rapid rise in groundwater level (Fig. 3). This produced 


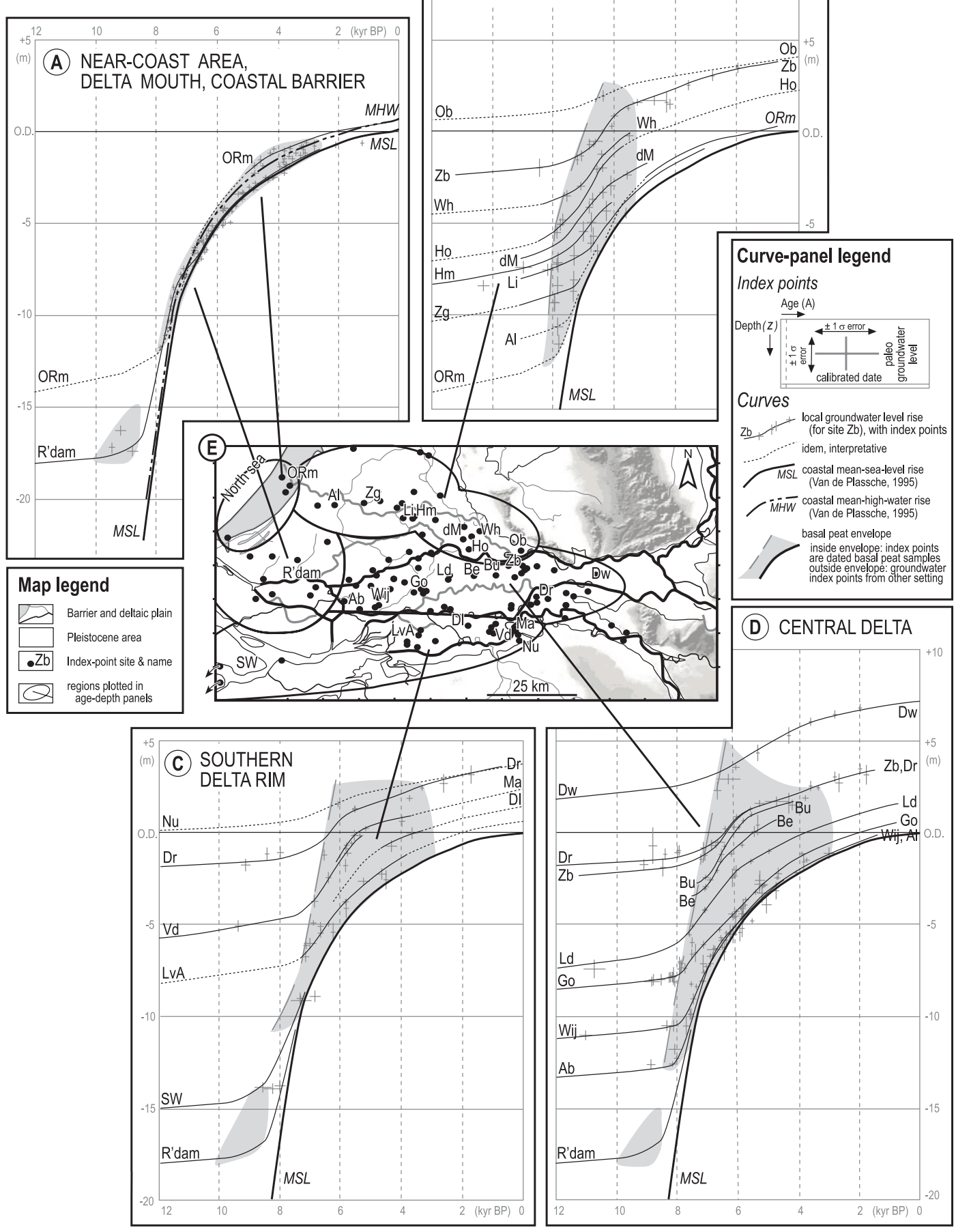

FIG. 3.-Data set for Holocene groundwater rise. Summary of data on Holocene groundwater rise in the Rhine-Meuse delta (van de Plassche, 1982, 1995; van Dijk et al., 1991; Törnqvist et al., 1998; Cohen, 2003; and other sources; see Berendsen and Stouthamer, 2001, their App. 1). Age-depth plots (panels A-D) of sites (grouped by region, panel E) show that groundwater rise after $~ 8 \mathrm{kyr}$ $\mathrm{BP}$ equals sea-level rise at near-coastal sites (panel A) and that series from more inland sites plot above MSL (panels B-D). For cross-reference, curves of near-coast sites R'dam - Rotterdam, ORm - Old Rhine mouth (Leiden), and central-delta sites Zb Zandberg, Dr - Dreumel are plotted in multiple panels. Other site-name abbreviations: (b) Al - Alphen a/d Rijn, Zg - Zegveld, Li - Linschoten, Hm - Harmelen, dM - de Meern, Ho - Houten, Wh - Werkhoven, Ob - Overlangbroek, (c) SW - South West Netherlands, Anna-Jacoba polder, LvA - Land van Altena, Dl - Delwijnen, Vd - Velddriel, Ma - Maren, Nu - Nuland; (d) Ab Alblas, Wij - Wijngaarden, Go - Goudriaan, Ld - Leerdam, Be - Beesd, Bu - Buren, Dw - Dodewaard. 
widespread and thick floodbasin peats from which the majority of the index points were sampled. Middle Holocene water-level rise can be reconstructed at a high temporal resolution, because series of dates are available that span a wide vertical range (e.g., $3 \mathrm{~m}$ ) and a short period (e.g., $1000 \mathrm{yr}$ ). In contrast, early Holocene groundwater-level records are far more condensed. Early Holocene index points differing in age by some $1000 \mathrm{yr}$ are collected from virtually the same vertical position (within $0.5 \mathrm{~m}$ ), indicating that rates of groundwater rise were significantly lower than in the middle Holocene. Good late Holocene groundwater-level index points are scarce too, mainly because extensive peat formation stopped and clay deposition in the upper and central delta increased (Pons, 1957; Verbraeck, 1984; Berendsen and Stouthamer, 2000). In addition, anthropogenic groundwater-level lowering for peat mining and land reclamation has largely destroyed the late Holocene floodbasin-peat record. Therefore, few late Holocene index points are available. Available late Holocene index points in the centralupper delta (Steenbeek, 1990; van Dijk et al., 1991) are from archaeologically dated soils within clayey floodbasin sediments. These clayey-soil-horizon index points likely represent settings proximal to a channel with higher overbank aggradation rates (e.g., Törnqvist and Bridge, 2002) than the distal floodbasins. Thus, because of their different settings, the available late Holocene index points from the central delta and upper delta are less accurate indicators of distal-floodbasin groundwater levels than their middle Holocene counterparts.

Compared to the errors $( \pm 0.15 \mathrm{~m})$ in reconstructing groundwater rise at high-resolution sampled sites (van de Plassche, 1982; van de Plassche and Roep, 1989; van Dijk et al., 1991; Törnqvist et al., 1998) the accuracy (eventually resulting after various GIS operations described in the Appendix) of this paper's envelope surfaces is lower and hard to quantify. The elevation error of the enveloping surfaces is estimated at $\pm 0.5 \mathrm{~m}$ for the ground water highstand and $\pm 0.5-1.0 \mathrm{~m}$ for the groundwater lowstand, on the basis of the accuracy of topographic input data and applied smoothing. The combined predictive power of the index-point data set and enveloping surfaces is in combining vertical resolution and lateral coverage. In the coastal prism (and in the paleovalley), paleogroundwater surfaces are generally smooth and only gently sloping, apart from local deformations due to differential subsidence (Cohen et al., 2002). Therefore, the application of groundwaterlevel age-depth relations over large distances is justified.

\section{INTERPOLATION METHODOLOGY}

The interpolation predicts paleo-groundwater levels between the lowstand level (LDEM) and the highstand level (HDEM), for which continuous surfaces were reconstructed independently (see Appendix). Data used in the interpolation are series of age-depth $(A, Z)$ combinations from multiple site locations $(X, Y)$. For an age $A$, the interpolation calculates a groundwater level $(Z)$ using the index points of age $A$, but also using higher and lower elevated points of younger, respectively older age. The method interpolates groundwater levels of all ages in the coastal prism at once: it is a truly 3D interpolation, not a series of stacked 2D interpolations. Two approaches were possible: (1) calculate an elevation for a given age: $Z=f(x, y, t)$; or (2) calculate an age for a given elevation: $A=f(x, y, z)$. Geological interpretations in terms of accumulation rates over time $(d Z / d t)$ were ultimately required, not a change of age with depth $(d A / d z)$. To estimate $d Z / d t$ at a constant temporal resolution (i.e., per $200 \mathrm{cal} \mathrm{yr}$ ), it is easier to calculate series of surfaces for given ages, than first to predict ages at given levels and subsequently distill surfaces of equal age from that. The $A=f(x, y, z)$ approach would demand nonlinear grids to achieve comparable temporal resolution over both more condensed, slowly aggrading parts and less condensed, rapidly aggrading parts of the record. The most straightforward approach is to estimate groundwater levels $(Z)$ at points defined by location $(X, Y)$ and age $(A)$.

The interpolation methodology consists of two parts: (1) an estimation of the 3D-trend function, capturing the overall continuously rising trend; and (2) a prediction of residuals with respect to the trend function, covering unexplained, local deviations of the regional trend.

The trend function is designed to describe both a time-invariant trend and a time-variant trend in the slopes $(d Z / d x, d Z / d y)$ of the paleo-groundwater surfaces. The time-invariant trend is the mean gradient over the whole data set, or, in other words, the mean gradient of all groundwater surfaces in the coastal prism. The time-variant trend $(d Z / d x \cdot d t, d Z / d y \cdot d t)$ is a decrease of gradient towards the highstand compared to the lowstand groundwater gradient. In the index-point data set, time-invariant and timevariant trends are superimposed. The groundwater lowstand and groundwater highstand are time-invariant: these are static groundwater surfaces representing snapshots in time (11 kyr BP respectively "present"). The bounding surfaces are used to incorporate the time-invariant trend. These surfaces (HDEM, LDEM; Fig. 4) are continuous, meaning that their levels are known at all index-point locations. The elevations $\left(Z_{i}\right)$ of the index points (Fig. $5 \mathrm{~A})$ are normalized to relative positions $\left(Z_{\%, i}\right)$ between the enveloping surfaces $\left(\operatorname{LDEM}_{X Y}, \operatorname{HDEM}_{X Y}\right)_{i}$ :

$$
Z_{\%, i}=\frac{\left(Z_{i}-\operatorname{LDEM}_{(X Y)_{i}}\right)}{(\operatorname{HDEM}-\operatorname{LDEM})_{(X Y)_{i}}}
$$

By normalizing the index-point data this way, the timeinvariant trend is partly removed. Equation 1 lines up the cloud of data points and produces a sigmoid curve (Fig. 5B). In geological terms, the resulting normalized value $\left(Z_{\%, i}\right)$ represents the percentage of coastal-prism thickness relative to the total accumulated thickness $\left(D_{i}\right)$ :

$$
D_{i}=(\operatorname{HDEM}-\mathrm{LDEM})_{(X Y)_{i}}
$$

Values for $Z_{\%}$ range between $0 \%$ at lowstand (11 kyr BP) and $100 \%$ for the present highstand.

\section{Trend Fitting of Groundwater Levels}

The trend remaining after normalization is modeled with a time-varying function that estimates these normalized groundwater elevations $Z_{\%, i}$ as a function of $X, Y$, and $A$. Let $p(t)=\left(A_{0}-\right.$ $\left.A_{i}\right) / A_{0}$ be a standardized value for the age $A$ of each data point, ranging from $p=0$ at the initial lowstand $\left(A_{i}=A_{0}=11,065 \mathrm{cal} \mathrm{yr}\right.$ $\mathrm{BP})$ to $p=1$ at present $(0 \mathrm{kyr} \mathrm{BP})$. Let $q_{(x, y)}=D_{X Y, i} / D$ be a standardized value of total accumulated thickness at location $X, Y$, relative to the average thickness for all index points $(D=$ $11.50 \mathrm{~m}$ ). The trend function was

$$
Z_{\%}(x, y, t)=\left\{(1-d) \cdot\left[1-\exp \left(-b \cdot q_{(x, y)} \cdot p_{(t)}{ }^{c}\right)\right]+d \cdot p(t)\right\} \times 100 \%
$$

with $\exp (a)=e^{a}$, and consists of a sigmoid term $(1-d)(1-\exp$ $\left.\left[-b \cdot q(x, y) \cdot p_{(t)}^{c}\right)\right]$ and a linear term $d \cdot p_{(t)}$. Both terms are $0(0 \%)$ at lowstand age $(p=0)$ and together add up to $1(100 \%)$ at present age $(p=1)$. Coefficients $b, c, d$ were fitted to the index points $\left(R^{2}=0.88\right)$. This yields 




\section{1 kyr cal BP}

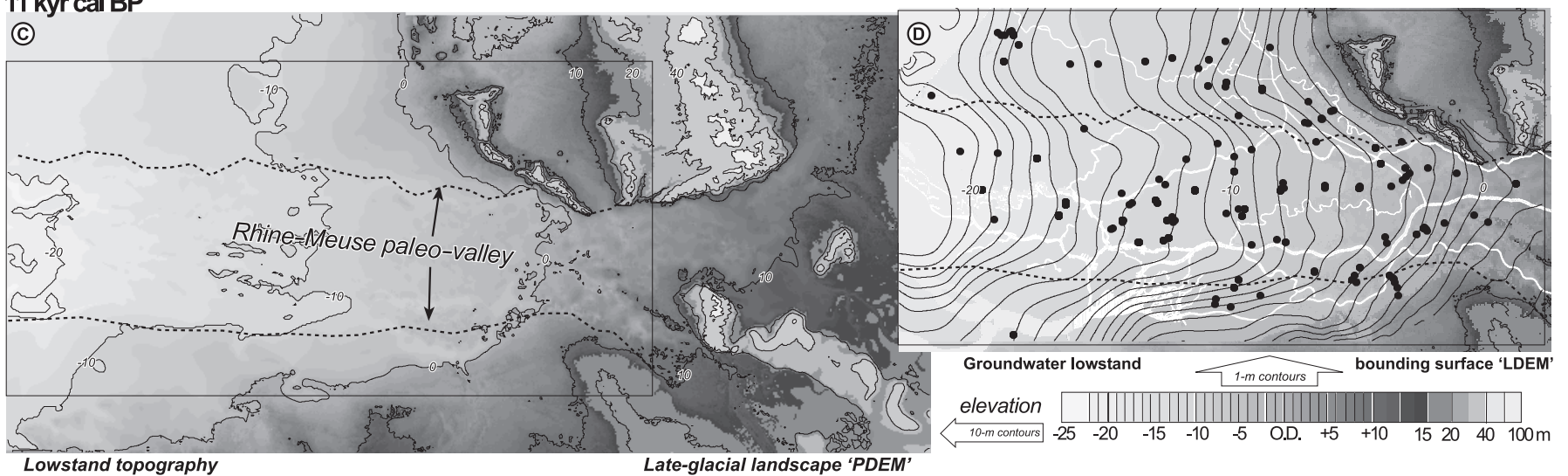

FIG. 4.-Holocene groundwater-rise envelope. Topographic elevation and groundwater level surfaces reconstructed for the present highstand and the $11.0 \mathrm{kyr}$ BP lowstand situations, in between which Holocene groundwater rise occurred. A) Digital elevation map of the present situation. Note the "polder" areas with artificially lowered surfaces meters below present MSL. B) Natural groundwater surface at the present situation (HDEM). C) Digital elevation map of Late-glacial topography (PDEM), based essentially on lithological borehole descriptions. D) $11.0 \mathrm{kyr}$ BP groundwater surface (LDEM), reconstructed exploring the relation between Late-glacial topography and groundwater-table depth (Appendix 1 ). All elevations are relative to O.D. $(\approx$ present MSL).

$\hat{Z}_{\% T, i}=\left\{(1-0.34)\left[1-\exp \left(-15.89 \frac{D_{X Y, i}}{\bar{D}}\left(\frac{A_{0}-A_{i}}{A_{0}}\right)^{3.40}\right)\right]+0.34\left(\frac{A_{0}-A_{i}}{A_{0}}\right)\right\} \times 100 \%$

with $D=11.50 \mathrm{~m}$ and $A_{0}=11065 \mathrm{cal}$ yr BP. The function varies from approximately linear to sigmoid, depending on timeinvariant function $q$ (Fig. 5C, left panel). This function (Equation 4) estimates $Z_{\%}$ for any observation location (index point) using its age $A$ and the total accumulated thickness $D_{X Y, i}$ at its location. To predict the regional trends, Equation 4 can be applied for any location $X, Y$ in the study area (i.e., where $D_{X Y}$ is known) and for any age between 11 and 0 cal kyr BP (i.e., essentially the entire Holocene). Note that predicted rise starts $\left(A=A_{0} ; p=0\right)$ at a lowstand below the paleo-valley surface $\left(\mathrm{LDEM}_{X Y}<\mathrm{PDEM}_{X Y}\right.$; see Appendix). The relative position of the paleovalley surface increases with decreasing thickness (Fig. 5D, right panel). Trend-fitted relative positions $\left(\hat{Z}_{\% T, i}\right)$ were converted to absolute elevations $\left(\hat{Z}_{T, i}\right)$ :

$$
\hat{Z}_{T, i}=\operatorname{LDEM}_{(X Y)_{i}}+\hat{Z}_{\% T, i}(\operatorname{HDEM}-\operatorname{LDEM})_{(X Y)_{i}}
$$

and next the residuals were calculated:

$$
\hat{Z}_{R, i}=Z_{i}-\hat{Z}_{T, i}
$$

\section{Kriging of Groundwater-Level Residuals}

Residuals from trend fitting (Fig. 5D) show approximately normal distributions, with the largest scatter around a total accumulated thickness $D$ between 5 and $10 \mathrm{~m}$ (i.e., at the transition between central and upper delta). This seems to indicate that regional deviations (caused by local controls) are superimposed on the general trend for the whole delta. Nearby data points (within 0-10 km distance and 0-2 kyr time difference) generally have highly correlated residuals, as is illustrated by their variograms (Fig. 6). It allows using "kriging" interpolation techniques (cf. Burrough and McDonnell, 1998), wherein residual variation remaining after trend fitting (Equations 1-6) is modeled as space-time autocorrelated variation plus uncorrelated variation (noise, nugget).

Absolute deviations from the trend (i.e. in meters, not in normalized units) were calculated. Using the GSTAT program (Pebesma, 1997; Pebesma and Wesseling, 1998) semivariograms 
(A)

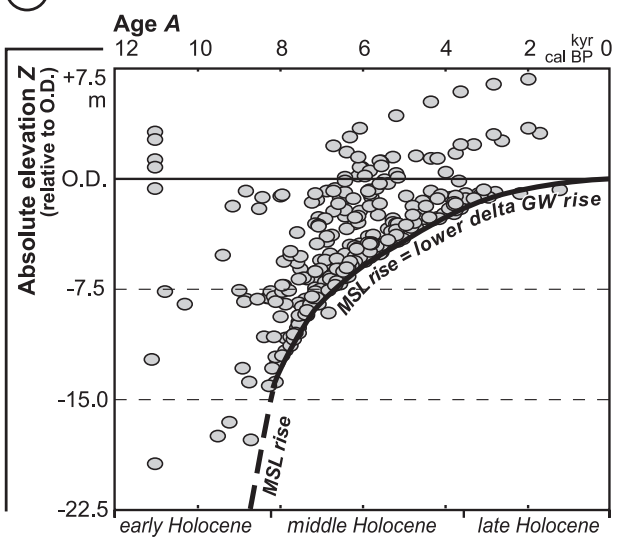

(B) NORMALIZED DATA

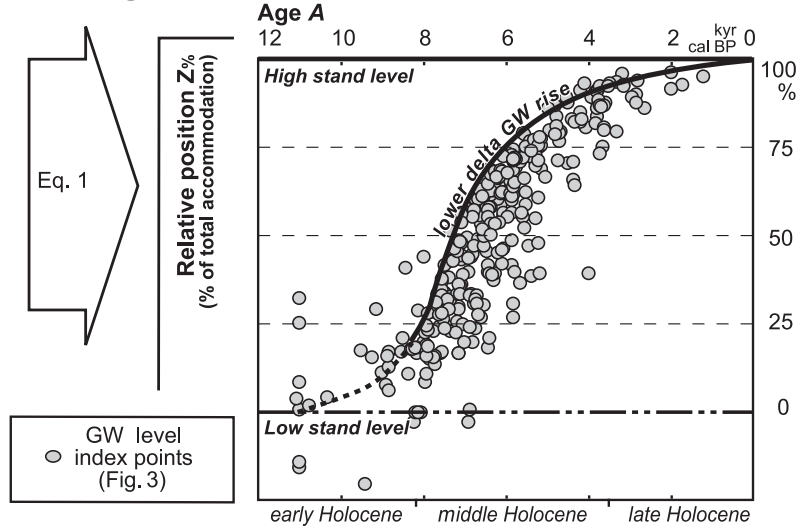

(C) TREND FUNCTION

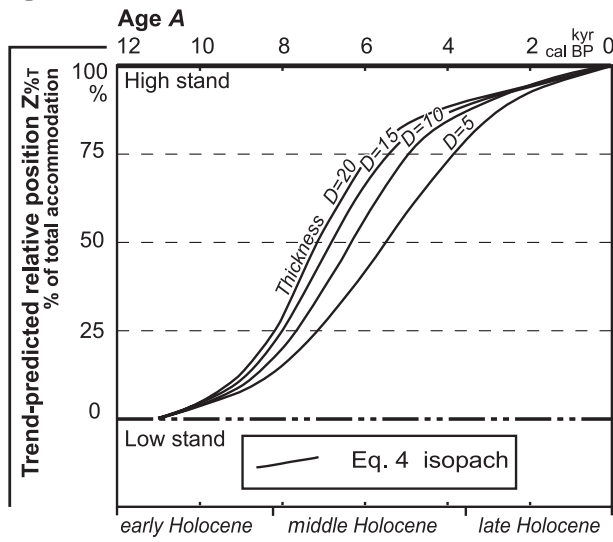

Total accommodated thickness $D$



(D) RESIDUAL ANALYSIS


FIG. 5.-Trend-fitted Holocene groundwater rise. Multi-panel plot illustrating the steps in data processing. A) Age-depth plot of data set for Holocene ground water rise (Fig. 3). Inland data plot above coastal data. B) Normalized data plot, age vs. relative vertical position (Z- $\left.-_{-}\right) .0 \%=$ lowstand, $100 \%=$ highstand, regardless of position in delta. C) Trend function (Equation 4) curve panels predicting $Z_{o}^{\circ}$ for any Holocene age $(A)$ and any local total-accumulated thickness $(D)$. Note the rightward shift in isopachs of decreasing thickness (left panel) and the upstream dip of the isochrone (right panel). These show differences in the timing of backfilling in the coastal prism. At more inland locations (e.g., where $D_{X Y, i}<7.5$ ), groundwater levels are trend-predicted below the paleovalley surface until the middle Holocene or even until the late Holocene (where $\left.D_{X Y, i}<2.5\right)$. In the western lower delta, by 6 cal kyr BP about $75 \%$ of the total thickness $(D=20 \mathrm{~m})$ had accumulated, while in the upper delta $(D=5 \mathrm{~m})$ by that time, only $40 \%$ of the total groundwater rise had occurred. D) Scatter plots and histograms showing the normal distributions of residuals after trend fitting, for relative position (Z- ${ }_{\%}$, upper panels) and absolute elevation ( $Z$, lower panels). 
of the residuals were constructed for the three dimensions $x, y$, and $t$ (Fig. 6). To avoid problems of singularity in the calculations, repetitive $X, Y$ combinations of index points from the same site have been altered slightly $( \pm 1-2 \mathrm{~m})$ so that no pair of index points has exactly the same $X$ and $Y$ coordinates. The variograms show the spatial to temporal range $(a)$ within which index points are autocorrelated and hence within which observations have predictive value with respect to deviations from the regional trend. The average semivariance $\gamma(h)$ for pairs of index points is calculated as a function of distance $h$ (see Pebesma, 1997; Pebesma and Wesseling, 1998) and is described by a spherical model (Table 1). Applied in a kriging interpolation, the fitted model decreases prediction standard error $\left(\sigma_{K}\right)$ by ca. $62 \%$, from $0.8 \mathrm{~m}\left(\sigma_{K}^{2}=0.7\right.$, sill value) to $0.3 \mathrm{~m}\left(\sigma_{K}^{2}=0.1\right.$, nugget value) at locations close (in space and in time) to index points.

Using the groundwater index-point residuals (313 observations) and the 3D variogram model (Table 1, Fig. 6) a kriging interpolation was performed. A set of prediction locations was defined for the delta gridded into $1 \mathrm{~km}$ by $1 \mathrm{~km}$ cells and the 11 kyr of Holocene time subdivided into $200 \mathrm{yr}$ time intervals. This set represents the coastal prism as 209,000 blocks (voxels) of $1 \mathrm{~km}$ x $1 \mathrm{~km} \times 200 \mathrm{yr}$, for which the regional trend was estimated (Equation 4) and the block-averaged residual value (block kriging; Burrough and McDonell, 1998) was predicted (GSTAT; Pebesma and Wesseling, 1998). No local neighborhood was specified in the interpolation; thus for any predicted ground water level all observations were weighted according to the $3 \mathrm{D}$ variogram. The output is a set of predicted residual values $\left(Z_{K}\right)$ and kriging variances $\left(\sigma_{K}^{2}\right)$ that was post-processed and visualized in the GIS.

\section{Post-Processing the Interpolation Results}

Several visualizations of the $3 \mathrm{D}$ matrix containing the results $Z(x, y, t)$ of the interpolation (i.e., trend + kriging prediction: $Z_{T}+$ $Z_{R}$ ) were made. Isochronous surfaces (time slices, Fig. 7) and cross sections (Fig. 8) were queried from the 3D matrix. Time slicing resulted in a stacked set of groundwater surfaces, which were used to estimate rates of groundwater-level rise $(d Z / d t)$ at each square $\mathrm{km}$ cell in the $X, Y$ grid as

$$
\left(\frac{d Z}{d t}\right)_{A}=\left(\frac{Z_{A-\Delta t}-Z_{A+\Delta t}}{2 \Delta t}\right) \cdot 10^{3} \mathrm{~m} / \mathrm{kyr}, \text { with } \Delta t=200 \mathrm{yr}
$$

for $10,000>A>2600$ cal yr BP in 200 yr intervals. To aid visualization, inverse distance interpolation was used to convert the dense network of points resulting from each query to continuous surfaces (grids).
At each location $(X, Y, A)$, kriging variances $\left(\sigma_{K}^{2}\right)$ were obtained simultaneously with the prediction $\left(Z_{K}\right)$. They are a measure of the accuracy of the interpolated values. Kriging variance increases with distance from observations (Table 1). Patterns in $\sigma_{K}^{2}$ thus reflect the spatial-temporal distribution of the data points. Because this distribution is determined largely by the geological setting (e.g., the center of the interpolated block produced more index points than other parts; see Introduction), differences in accuracy exist between central and marginal parts: $\sigma_{K}^{2}$ varies from higher values (low accuracy) in marginal areas to lower values (maximum accuracy) in densely sampled spatiotemporal domains (Figs. 7B, 8). This is in agreement with the predictive quality of the input data. Because data density is largest for the middle Holocene, along the central delta axis, prediction variance is lowest (minimum: $0.2 \mathrm{~m}$ ). In the temporal domain, reconstructed groundwater levels for the middle Holocene are most reliable. In contrast, early and late Holocene records are relatively condensed, and therefore have a reduced accuracy (Fig. 8). In the spatial domain, reconstructions for the extreme NW, SW, and E (i.e., downstream and upstream marginal areas) are less reliable than in the central delta (Fig. 7B).

Extensive tidal and estuarine erosion of basal peat has occurred west of Rotterdam. Remaining patches were sampled only occasionally, producing few index points and hence reduced accuracy. In the most upstream part of the study area, basal peat was not formed. Here, a few index points come from A horizons of paleosols in floodbasin deposits (Steenbeek, 1990). In these upstream reaches, the floodbasin groundwater level was not necessarily the depositional surface, reducing accuracy (see Introduction).

\section{Assessment of Interpolation Quality: Cross-Validation}

Age-depth data based on basal peats is the most accurate proxy for groundwater rise on Holocene time scales. For the late Holocene, archaeology may potentially provide quantitative indications of similar quality. Sedimentary and pedogenic features (immaturity of the paleosols, depth of specific horizons) that can also be used as indicators for groundwater rise generally have lower age-depth resolution and accuracy. An integrated database of such features, allowing quantitative queries with a spatial coverage comparable to the basal-peat data set, is not yet available. To construct such a database remains a future task and is mainly a matter of design and administration. Collecting new data in the Rhine-Meuse delta for this purpose is less important, because available numbers of boreholes are already huge and of unprecedented detail. Independent data to validate the results of the interpolation are not available. The interpolation result was par-

TABLE 1.-The fitted 3-D anisotropic spherical variogram model (Fig. 6).

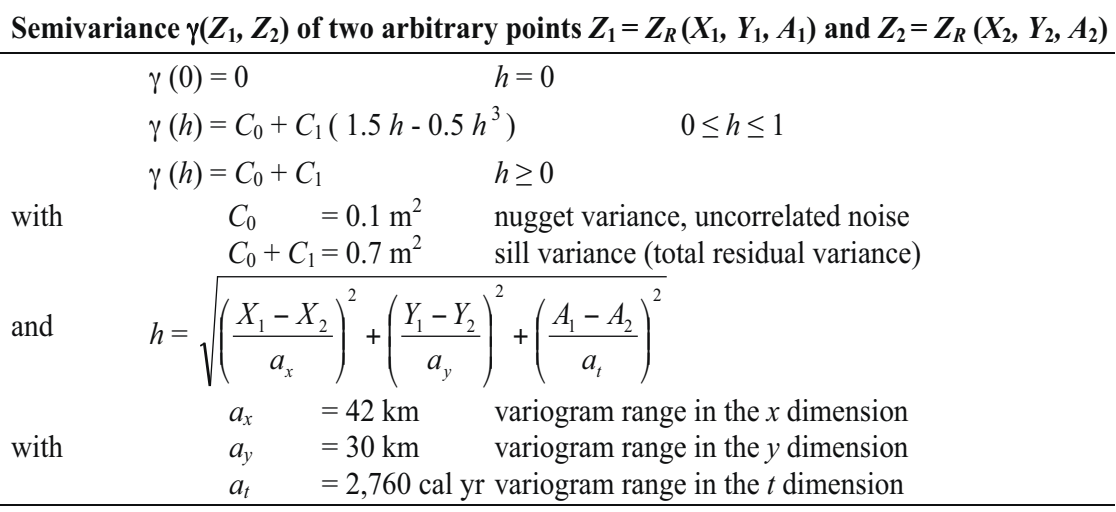






FIG. 6.- Residual variance variograms. Residual spatio-temporal autocorrelation remaining after trend fitting is quantified as directional variograms for the three dimensions. Panels show unidirectional projections of the 3D spherical variogram model for each dimension: A) Age $A$; B) Easting $X$; C) Northing $Y$. The ranges $\left(a_{t}, a_{x}, a_{\mathrm{y}}\right)$ are estimated by fitting to the projected data (using GSTAT; Pebesma and Wesseling, 1998), and their ratios define the geometric anisotropy of the $3 \mathrm{D}$ variogram model (Table 1). Nugget $\left(C_{0}=0.1 \mathrm{~m}^{2}\right)$ and sill $\left(C_{0}+C_{1}=0.7 \mathrm{~m}^{2}\right)$ values are equal for all curves; their values are based on the residual distributions (Fig. 5D).

tially cross-validated, to test the accuracy of the trend-function estimates and the kriging-predicted residuals. Cross-validation concentrated on the more densely sampled parts of the data set. Cross-validation at the boundaries of the interpolated domain (e.g., for the periods 11.0-9.5 kyr BP and 3.0-0 kyr BP, which are "near the envelope") was not attempted. In these areas, index points are scarce and hence results are strongly determined by only a few availablepoints. Furthermore, results "neartheenvelope" arestrongly determined by the local value of the bounding surface, and crossvalidation would mainly reflect the larger uncertainty of that value.

Cross-validation to assess the quality of the interpolation was performed for the center of the interpolated block by excluding various selections of index points. Results were compared to a reference result, using all index points. The selection of index points was found to be critical. Coefficients of fitted trend function (Equation 4; Fig. 5C) and variogram model (Table 1, Fig. 6) were cross-validated by deselecting randomly picked individual index points from the total data set, but they hardly deviated from the reference-run coefficients. Only when entire regions (e.g., all data from the Southern delta rim, Fig. 3) were excluded did fitted coefficients change significantly. The kriging procedure was tested by deselecting groups of index points. This was done for a time interval (6.5 and $5.6 \mathrm{cal} \mathrm{kyr} \mathrm{BP}$, a time period spanning $30 \%$ of the variogram range $a_{t}$ ) and subsequently for five localities (sites Ab, Ld, Bu, Ho, Dl; Fig. 3). The first is the most extreme test. Reconstructing the ground water table for $6 \mathrm{kyr} \mathrm{BP}$, after deselecting about one third of the data points resulted in deviations ranging from $-0.4 \mathrm{~m}$ to $+0.6 \mathrm{~m}$ (Table 2). Exclusion of data points from a single site has only a local effect, with larger deviations ($0.3 \mathrm{~m}$, Table 2) at more isolated sites (sites Ld, Dl; Fig. 7).

All cross-validation results are considered good and confirm the a priori assumed predictive quality of the peat samples as a proxy for paleo-groundwater levels. Differences in elevations in the cross-validation runs remain within one standard deviation $(\sigma)$, the maximum kriging standard error (Table $1: \sigma_{K, \max }=\sqrt{ }\left(C_{0}+C_{1}\right)$ $=0.8 \mathrm{~m})$. The minimum kriging standard error $\left(\sigma_{K}\right)$ as derived from fitting the variogram model (Table $1: \sigma_{K, \min }=\sqrt{ } C_{0}=0.3 \mathrm{~m}$ ) is similar to the accuracy of the index points (0.2-0.3 m; Input Data section). Interpolated groundwater surfaces mimic independently reconstructed (see Appendix) highstand and lowstand surfaces as intended. Over space, in between data points, gradual transitions are produced, resulting in gentle slopes and smooth surfaces. Over time, at individual sites, this results in gradually rising groundwater levels, producing age-depth curves similar to earlier exponential fits for local sites (Fig. 3; e.g. van Dijk et al., 1991; van de Plassche, 1995; Kiden, 1995; Törnqvist et al., 1998). Therefore, reconstructed paleo-groundwater surfaces are considered to be realistic and the interpolation method robust. Spatialtemporal patterns, in particular those in the center of the interpolated 3D block, are explained primarily by geological processes, not as artifacts produced by the interpolation methodology.

\section{RESULTS: GEOLOGICAL INTERPRETATION}

Patterns of the paleo-groundwater rise in the coastal prism are compared to the lowstand and highstand state, to identify the interplay and spatio-temporal shifts in dominant controlling factors. The lowstand and highstand situations (Fig. 4) are the end members for paleo-groundwater surfaces (Figs. 7, 8) interpolated at $200 \mathrm{yr}$ intervals. The ground water lowstand is considered to be dominantly upstream-controlled, whereas the highstand is dominantly downstream-controlled.

\section{Middle-Late Holocene Controls}

\section{Sea-Level-Controlled Groundwater-Level Rise.-}

Maximum rates of groundwater-level rise $(\sim 5.3 \mathrm{~m} / \mathrm{kyr}$, Fig. 9$)$ are reconstructed for ca. $8.2 \mathrm{cal} \mathrm{kyr} \mathrm{BP}$ in the Rotterdam area ( $R^{\prime}$ dam, Fig. 3). The main body of the coastal prism accumulated 


\section{D-interpolated coastal prism groundwater}
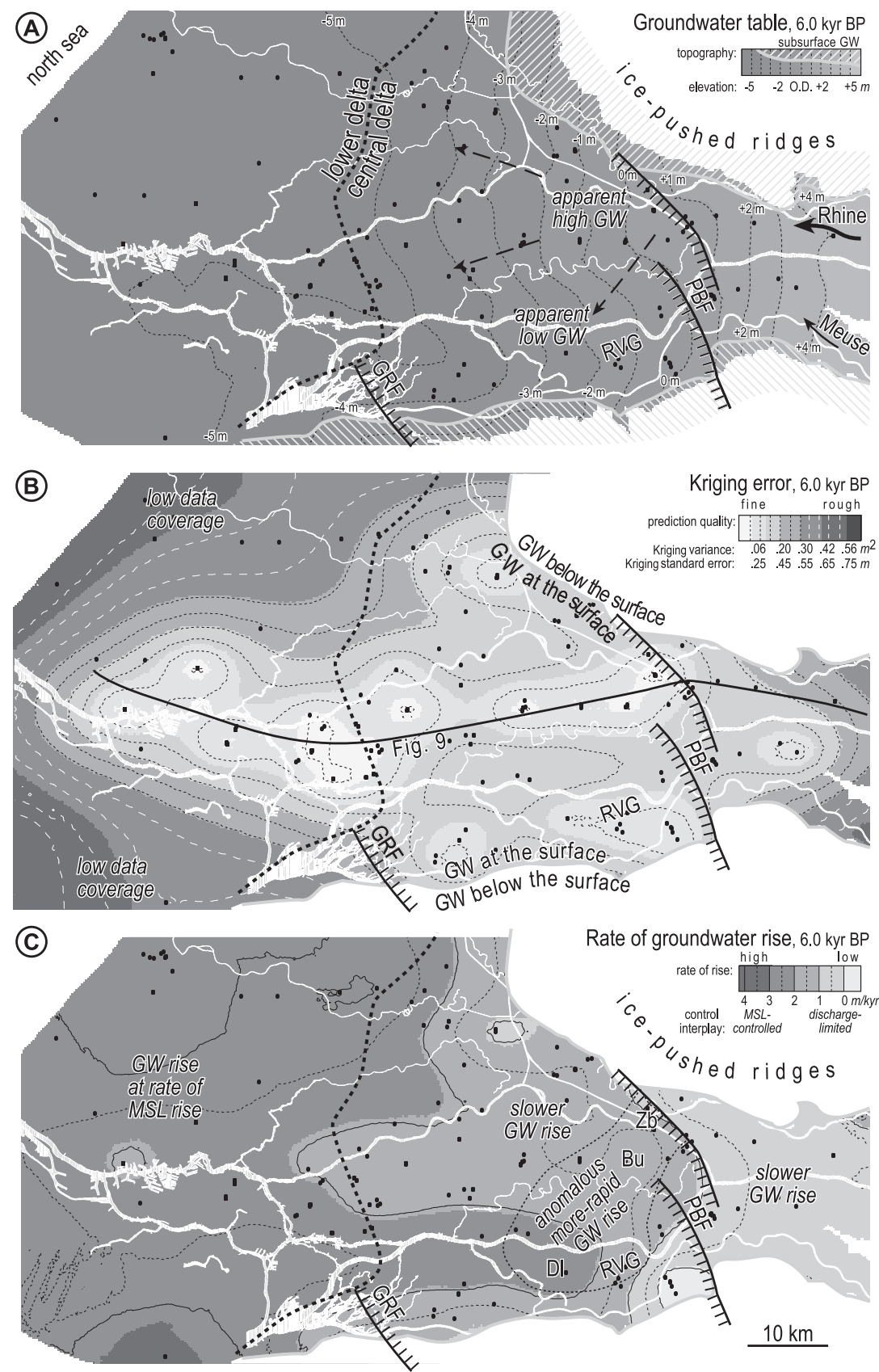

- primary input data; 321 groundwater index-points $11.0-2.0 \mathrm{kyr}$ cal BP

FIG. 7.-3D-interpolated coastal-prism groundwater. Maps visualizing the 3D-geostatistical interpolation result at 6.0 cal kyr BP. Site name abbreviations are as in Fig. 3; modern rivers and tectonic structures are added for reference (RVG, Roer Valley Graben; PBF, Peel Boundary Fault zone; GRF, Gilze-Rijen Fault zone). Regions that were not yet deltaic (i.e., had subsurface groundwater levels) are cross-hatched in Part A and masked from Parts B and C. The boundary between the lower and central delta is based on a concave break in groundwater slope. GW = groundwater. A) Elevation of the $6.0 \mathrm{kyr}$ BP paleo-groundwater table $(Z)$. By this time, the extent of the delta was close to the present one. The map shows the present elevation of the 6.0 kyr $\mathrm{BP}$ paleo-groundwater level-because of subsidence this is not the elevation at which it originally may have been. In the southern part of the central delta (the actively subsiding RVG) it is below that of the northern part. Dashed arrows indicate directions of maximum gradient, diverging from the longitudinal delta axis. B) Kriging prediction error $\left(\sigma_{K}\right)$ for $6.0 \mathrm{kyr} B P$, indicating spatial distribution of interpolation quality. Low values occur closest around index points dated to $\sim 6.0 \mathrm{kyr}$ BP. C) Rate of groundwater rise $(d Z / d t)$ for $6.0 \mathrm{kyr} \mathrm{BP}$. Rates for the central delta are below rates for the lower delta: inland the effect of sea-level rise was limited by discharge. Superimposed on the regional trend, anomalous high rates of groundwater rise are observed in the RVG, downstream of the PBF. 




FIG. 8.-3D-interpolated groundwater-level gradients. 3D-geostatistical interpolation, visualized as a longitudinal section through the delta. The error in kriging prediction $\left(\sigma_{K}\right)$ indicates the local interpolation quality. Low values occur around index points located close to the section. Projected position of shoulders of Roer Valley Graben are indicated by cartoons of fault zones (GRF and PBF). Location of section is similar to that of van Dijk et al. (1991).

after $8.2 \mathrm{kyr}$ BP, i.e., in the middle Holocene. Between 9.5 and $8.2 \mathrm{cal}$ $\mathrm{kyr} \mathrm{BP}$, the rate of rise gradually increased. After $8.2 \mathrm{cal} \mathrm{kyr} \mathrm{BP} \mathrm{rates}$ decreased, dropping below $1 \mathrm{~m} / \mathrm{kyr}$ at approximately 4 cal kyr BP. The geological interpretation for this is that sea level became a direct control by $8.2 \mathrm{cal} \mathrm{kyr} \mathrm{BP}$; since that time, groundwater-level rise in the Rotterdam area resembled relative sea-level rise at the river mouth (Jelgersma, 1961; van de Plassche, 1982, 1995) and the study area had largely become actively aggrading. Before that time, river discharge dominated ground water gradients and limited the rates of groundwater rise in the study area, which was actively transforming from a fluvial valley to an aggrading fluvial delta (the onset of the eventual coastal prism).

\section{Discharge-Controlled Inland Groundwater Rise.-}

After $8.2 \mathrm{cal}$ kyr BP, not only in the lower delta, but also in the central delta, rates of groundwater rise were strongly controlled by sea level. Sea-level rise lifted inland groundwater levels, just as it lifted lagoonal groundwater levels directly behind the barrier. The same general temporal trend (rapid middle Holocene rise, decelerating towards the late Holocene) is present. This is illustrated by the broadly similar shapes of groundwater curve from the lower and the central delta (Fig. 3). However, in more detail, dissimilarities are present. For example, while sea level at the river mouth was rising at rates of $>3 \mathrm{~m} / \mathrm{kyr}$ at $6.0 \mathrm{kyr} \mathrm{BP}$, contemporary inland groundwater levels were rising at slower rates (Fig. 7). This is an effect of the fluvial gradient that is maintained in inland groundwater levels (van Dijk et al., 1991) because of continuous inflowing river discharge. After $8.2 \mathrm{kyr} \mathrm{BP}$, sea-level rise decreased the inland groundwater-level gradients, while lifting the groundwater table. Where sea-level rise had eventually transformed the fluvial delta into a lagoon (= the lower delta), gradients became nearly horizontal $(\sim 0.01 \mathrm{~m} / \mathrm{km})$ and rates of groundwater-level rise did approach rates of sea-level rise. In the central delta, sea-level rise did alter antecedent river-controlled groundwater gradients that had become established before $(\sim 0.2 \mathrm{~m} / \mathrm{km})$ but did not eventually transform it into a lagoon. The groundwater gradients in these areas were reduced $(\sim 0.13 \mathrm{~m} / \mathrm{km})$ but did not approach lagoonal values. As a consequence, groundwater-level rise in the backbarrier delta, although forced by sea-level rise, did not occur at the rate of sea-level rise, but at a reduced rate.

\section{Transition of Central to Lower Delta.-}

The (paleo) groundwater surfaces have a concave gradient with a pronounced break in slope. This break marks the transition 
TABLE 2.-Cross-validation of kriging-interpolated groundwater levels at 6.0 kyr BP.

\begin{tabular}{|c|c|c|c|c|c|c|}
\hline \multirow{2}{*}{$\begin{array}{l}\text { Cross-validation tests } \\
\text { Data used }\end{array}$} & \multicolumn{4}{|c|}{ Location (Fig. 3) } & \multirow[b]{2}{*}{ Ho } & \multirow[b]{2}{*}{ Dl } \\
\hline & $N$ & $\mathrm{Ab}$ & $\mathrm{Ld}$ & $\mathrm{Bu}$ & & \\
\hline Reference run (all data) & & \multicolumn{5}{|c|}{ Groundwater level at $6.0 \mathrm{kyr} B P[\mathrm{~m} \pm$ O.D. $]$} \\
\hline Trend estimate $Z_{T}$ & 313 & -5.36 & -4.01 & -1.76 & -1.88 & -2.53 \\
\hline Kriging predicted deviation $Z_{K}$ (Fig.6) & 313 & -0.55 & 1.14 & 1.34 & 0.43 & -0.54 \\
\hline Interpolation result $Z=Z_{T}+Z_{K}$ (Fig.7) & 313 & -5.91 & -2.87 & -0.43 & -1.45 & -3.08 \\
\hline Kriging validation runs & & \multicolumn{5}{|c|}{ Predicted difference with reference run [m] } \\
\hline $\begin{array}{l}\text { Excluding all points dating } \\
\text { between } 6.5 \text { and } 5.6 \mathrm{kyr} \text { cal BP }\end{array}$ & 220 & +0.54 & -0.31 & -0.33 & -0.09 & -0.15 \\
\hline $\begin{array}{l}\text { Excluding } 13 \text { Alblasserdam }(\mathrm{Ab}) \text { points } \\
\text { lower-central delta transition }\end{array}$ & 300 & -0.01 & 0 & 0 & 0 & +0.02 \\
\hline $\begin{array}{l}\text { Excluding } 9 \text { Leerdam }(\mathrm{Ld}) \text { points } \\
\text { central delta center }\end{array}$ & 304 & 0 & -0.32 & 0 & -0.03 & 0 \\
\hline $\begin{array}{l}\text { Excluding } 6 \text { Buren }(\mathrm{Bu}) \text { points } \\
\text { central-upper delta transition }\end{array}$ & 307 & 0 & 0 & -0.08 & 0 & 0 \\
\hline $\begin{array}{l}\text { Excluding } 7 \text { Houten }(\mathrm{Ho}) \text { points } \\
\text { central delta-northern rim transition }\end{array}$ & 306 & 0 & 0 & 0 & +0.11 & -0.01 \\
\hline $\begin{array}{l}\text { Excluding } 3 \text { Delwijnen }(\mathrm{D} 1) \text { points } \\
\quad \text { central delta-southern rim transition }\end{array}$ & 310 & 0 & 0 & 0 & +0.01 & -0.28 \\
\hline
\end{tabular}

from the lower delta to the central delta, i.e., the transition between a lagoonal area where marine controls are dominant, and a fluvial area where upstream controls interplay with downstream controls. The break in slope was earlier recognized by van Dijk et al. (1991; their "knick-point", p. 323), who suggested that it had migrated ca. $10 \mathrm{~km}$ upstream since $7 \mathrm{kyr}$ BP. The geostatistical interpolation does not confirm this result: after $7 \mathrm{kyr}$ BP the concavity remained at approximately the same position (Fig. 8). However, the interpolation shows that considerable upstream migration did occur prior to $7 \mathrm{kyr} \mathrm{BP}(20 \mathrm{~km}$ between 8.2 and 7.0 cal kyr BP; Fig. 8), as a result of sea-level rise.

\section{Early Holocene (before 8.2 cal kyr BP) Controls}

Before $8.2 \mathrm{cal}$ kyr BP, the absence of a clear break in longitudinal slope implies that conditions like those of the present lower delta did not exist in the study area (but they may have existed in the present offshore area). Few groundwater index points older than $8.2 \mathrm{kyr} \mathrm{BP}$ (Fig. 3A) exist, because of sampling difficulties at large depth relative to the present surface $(-12$ to $-20 \mathrm{~m}$ ). Available index points dating from 9.0 to $8.2 \mathrm{kyr}$ cal BP come from clearly fluvial settings in the central and upper delta but are absent in the lower delta (Fig. 3A: R'dam sites). In the absence of data, the interpolation of groundwater levels suggests a gradual rise (Equation 4). To check if such a gradual increase is realistic, the local record and the implications of the interpolation outcome are briefly reviewed. In the lower delta, basal peat at a depth between 12 and $15 \mathrm{~m}$ below O.D. is rare: available basal-peat dates come either from below $-15 \mathrm{~m}$ and predate $9 \mathrm{kyr} \mathrm{BP}$, or from above $-12 \mathrm{~m}$ (relative to O.D.) and are younger than $8.2 \mathrm{cal} \mathrm{kyr} \mathrm{BP}$. In the $3 \mathrm{~m}$ in between, brackish lagoonal-lacustrine silty clays, onlap compaction-free surfaces (e.g., de Groot and de Gans, 1996; Berendsen and Stouthamer, 2001; personal observation). The fact that over some time span peat did not form, but other lagoonal deposits (related to greater water depths) did, suggests that these resemble a period or event of extremely rapid groundwater rise. Given the dating accuracy of \pm 200 cal yr, gradual accumulation at the interpolated maximum rate $(5.3 \mathrm{~m} / \mathrm{kyr}$, derived from the peat directly overlying the lagoonal deposit) may just span the entire agedepth interval ( $3 \mathrm{~m}$ in $800 \mathrm{yr}$ ), but this would imply that the lagoonal deposit accumulated at the same rate as groundwater rise, i.e., at near-zero water depths, which does not match its sedimentological characteristics). In reality, rates must have increased more abruptly, some centuries later than $9.0 \mathrm{kyr} \mathrm{BP}$, to explain why no peat formed in the three meters below $-12 \mathrm{~m}$. Therefore, the gradually increasing rate between 9.0 and $8.2 \mathrm{kyr}$ $\mathrm{BP}$ is interpreted as an interpolation artifact, and it is probable that maximum interpolated rate $(5.3 \mathrm{~m} / \mathrm{kyr}$ at $8.2 \mathrm{kyr} \mathrm{BP})$ was preceded by a short period of even higher rates. The onset of this more abrupt rise (possibly a eustatic sea-level-rise event), is constrained to the central part of the $800 \mathrm{yr}$ age gap, most probably between 8.7 and $8.4 \mathrm{cal}$ kyr BP.

\section{Control of Tectonic Subsidence}

\section{Regional and Local Effects.-}

Like sea-level rise, groundwater rise in the southern North Sea basin consists of a eustatic-rise component and a subsidence component. Relative water-level rise continued in the late Holocene in the southern North Sea, while by that time global eustatic sea-level rise had virtually ceased (e.g., Peltier, 2002). This illustrates that tectonic subsidence is a significant factor. 


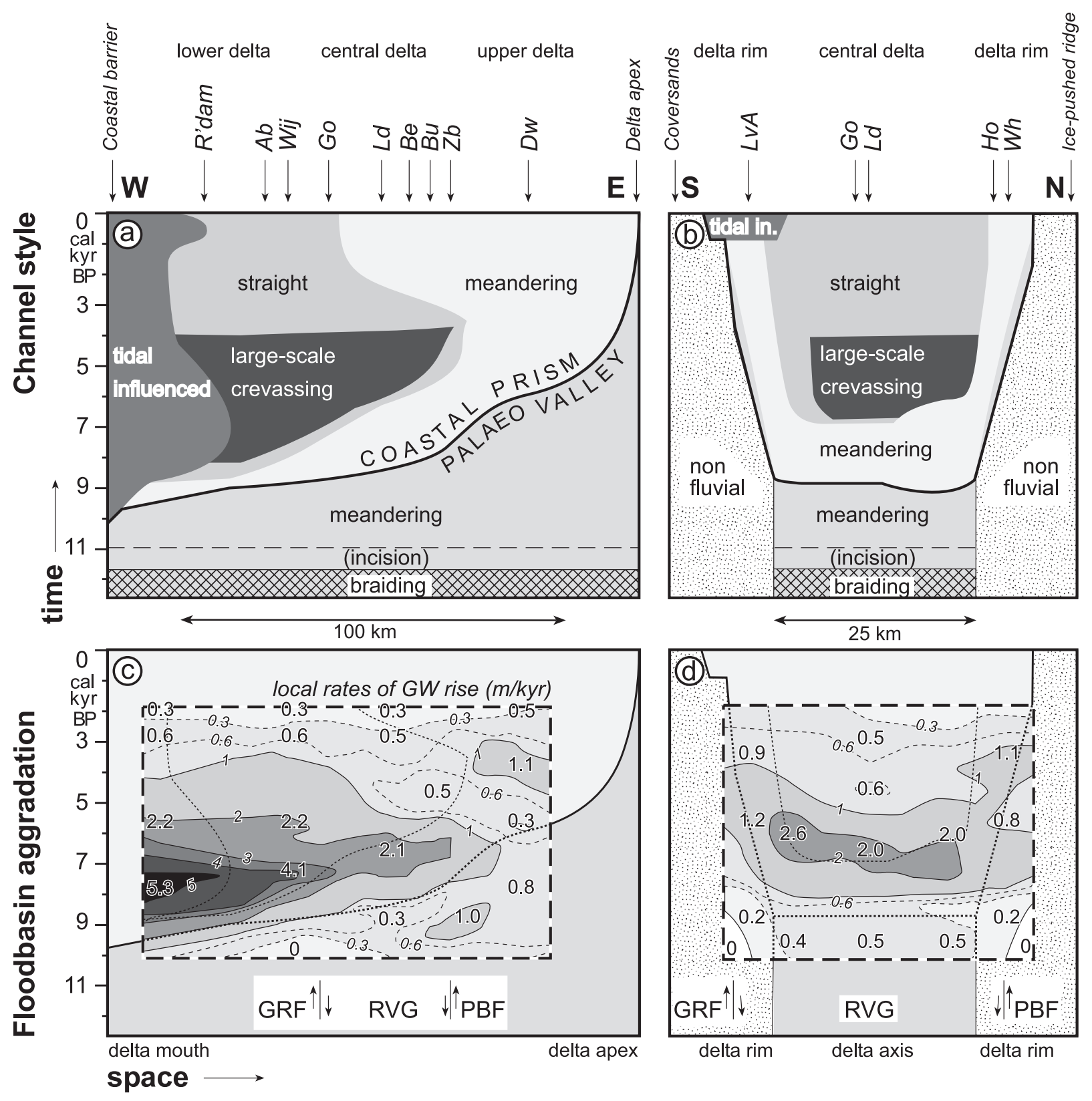

FIG. 9.-Channel style and floodbasin aggradation. Space-time diagrams along longitudinal (W-E) and lateral (S-N) transects through the coastal prism. A-B) Upper panels after Törnqvist (1993), with modifications. Channel type names, cf. Makaske (1998), Berendsen and Stouthamer (2001). Site-name abbreviations are as in Fig. 3. C-D) Lower panels plot interpolated floodbasin aggradation rates (this study), which are a primary control on style of deltaic channels.

Subsidence co-influences accommodation attributed to relative sea-level rise. Breaking down relative rise into eustatic and subsidence components is usually not attempted, or impossible given data availability. Hence, lumping eustasy and subsidence controls in geological interpretation of near-coastal fluvial records is a common approach (e.g., Blum and Törnqvist, 2000). While eustatic sea-level rise is spatially uniform, tectonic subsidence is spatially variable (as a result of tilting and differential subsidence of the subsurface; Cohen et al., 2002; Cohen, 2003). In the interpolation approach, relative rise was estimated by a trend function (Equations 3, 4). The coefficients in Equation 4 accounted for the overall downstream-increasing trend in subsidence, while kriging of the residuals accounted for the remaining nonlinear spatial variation. This way, the interpolation dealt with both regional and local effects: the effect of absolute subsidence is part of the regional trend, and local effects of differential subsidence can be identified as sub-regional patterns superimposed on the regional trends.

Differential subsidence can be an additional local control creating extra accommodation. This is relevant for the $\mathrm{E}-\mathrm{W}$ oriented Rhine-Meuse rivers, because they cross tectonic blocks, fault zones, and Quaternary depocenters rather than following the main SE-NW orientation of the tectonic framework (Cohen et 
al., 2002). It is now accepted that differential subsidence associated with the Roer Valley Graben (RVG) was a significant control in the central delta (Berendsen and Stouthamer, 2000, 2001; Cohen et al., 2002). The central-upper delta transition coincides with the NE edge of the RVG (the Peel Boundary Fault zone; PBF). The SW edge (the Gilze-Rijen Fault zone; GRF) of the RVG is within the lower delta (Fig. 7). Locally, differential subsidence across the PBF ranges from $0.03-0.07 \mathrm{~m} / \mathrm{kyr}$ at the central delta axis to $0.09-0.15 \mathrm{~m} / \mathrm{kyr}$ in the southern delta rim. Local offsets of the paleovalley surface are between 0.8 and $1.5 \mathrm{~m}$ (Cohen et al., 2002; Cohen, 2003). These are values averaged over 7,000-15,000 years. They are 1-2 orders of magnitude smaller than middle Holocene rates of relative water-level rise and could therefore be considered of low significance. However, differential subsidence has not necessarily been constant over time. Locally, short-duration periods characterized by large displacements (e.g., swarms of earthquakes; Houtgast et al., 2003; Houtgast, 2003) may have alternated with longer periods with hardly any displacement. Hence, averaged over periods of 100-1000 yr, subsidence rates locally may have contributed significantly to relative groundwater-level rise, have influenced regional aggradation rates, and have deformed paleo-groundwater gradients. Indeed, detailed studies of the Holocene floodbasin aggradation across the PBF (Törnqvist et al., 1998; Cohen et al., 2002; Cohen, 2003) indicated locally higher rates of subsidence immediately downstream of the PBF, than farther downstream. This pattern is also produced by the interpolation (e.g., the zone of anomalously rapid groundwater rise at $6.0 \mathrm{kyr} \mathrm{BP}$ in Fig. 7C). Thus, local temporarily more rapid floodbasin aggradation can be explained as the effect of temporarily higher subsidence rates, implying a syndepositional effect on contemporary peat formation. Apart from these syndepositional effects, postdepositional effects may also appear in records of groundwater rise. Anomalies in paleo-surface elevations may result from postdepositional deformation across fault zones, similar to tectonic deformation of fluvial longitudinal profiles (Cohen et al., 2002). Indeed, towards areas of greatest subsidence, deformation of paleo-groundwater surfaces progressively increased gradients. For example, contour lines in the 6.0 kyr BP time slice (Fig. 7A) align parallel to the PBF strike: maximum gradients in Figure 7A are to the SW, perpendicular to the PBF, and not perpendicular to the coast. In conclusion, anomalies in rates of groundwater rise and in present elevation of paleo-groundwater levels indicate that differential subsidence (by syndepositional and postdepositional effects) was an active local control in floodbasin aggradation, as identified earlier (Törnqvist et al., 1998; Cohen et al., 2002; Cohen, 2003).

\section{Implicitly Quantified Absolute Subsidence Rates.-}

The trend function (Equation 3) was designed to mathematically model the downstream-upstream interplay: the eustatic component in relative rise is in the sigmoid term, and the subsidence component in groundwater rise is in the linear term of Equation 3. The fitted value for coefficient $d$ in Equation 3 is an estimate of mean absolute subsidence in the study area, relative to the local thickness of the sedimentary wedge, and averaged over the last $11,000 \mathrm{yr}$. Its value $d=0.34$ (Equation 4 ) implies that over $11 \mathrm{kyr}, 34 \%$ of the locally accumulated thickness $(D)$ is accounted for by linear rise. Because thickness $D$ increases downstream, the absolute amount accounted for by the linear term also increases downstream. For a location with a total accumulated thickness $D=12 \mathrm{~m}$, a linear rate of $D \cdot d / 11 \mathrm{kyr}=\left(12^{*} 0.34\right) / 11=$ $0.37 \mathrm{~m} / \mathrm{kyr}$ is implicitly applied. For $D=6 \mathrm{~m}$, the rate is $0.19 \mathrm{~m} /$ $\mathrm{kyr}$. This way the trend function accounts for the general downstream-increasing trend in absolute subsidence. The linear term cannot be fully attributed to subsidence because a linear component of eustatic sea-level rise may also be embedded in the estimate. The linear term defines the maximum rate of Holoceneaveraged subsidence that may have occurred. Values are about 200-300\% higher than estimates for absolute subsidence over longer time scales (e.g., Kiden et al., 2002: $0.16 \mathrm{~m} / \mathrm{kyr}$ for the Rotterdam area, averaged over $125 \mathrm{kyr}$ since OIS $5 \mathrm{e}$ ). Kiden et al. (2002) deduced relatively high subsidence rates in the study area during the early and middle Holocene, and explained this as a result of postglacial forebulge collapse (resulting from the glacioisostatic effect of melting icecaps on Britain and Scandinavia) and water loading (resulting from eustatic sea-level rise in the North Sea Basin). Although the implicitly quantified rates for absolute subsidence are maximum estimates, which probably overestimate actual rates, they support results by Kiden et al. (2002). Postglacial rates of subsidence in the study area were higher than longer-term averages over complete glacial cycles, because of the collapse of a forebulge that had built up in the preceding part of the last glacial.

\section{Local Differential Subsidence Quantified by Kriging.-}

Paleo-groundwater gradients across the PBF zone may have been displaced by fault activity (Törnqvist et al., 1998; Cohen et al., 2002). Fault displacement is seen as local, relative subsidence, superimposed on absolute subsidence (i.e., local differential subsidence). For older groundwater gradients, the displacement will be larger. A linear rate of fault displacement can be estimated from elevations of paleo-groundwater levels at opposite sides of the fault, after correction for elevation differences caused by regional trends. The residuals $\left(Z_{R} ;\right.$ Equation 6$)$ are relative elevations remaining after removal of such regional trends. Upstream of the PBF, a component of $Z_{R}$ can be attributed to fault displacement. The kriging part of the interpolation was further developed to quantify this component. The effect of fault displacement in the residuals was incorporated as:

$$
\begin{cases}\hat{Z}_{R, i}=\hat{Z}_{K, i}+s \cdot A_{i} \cdot 10^{-3} & \text { upstream of the PBF } \\ \hat{Z}_{R, i}=\hat{Z}_{K, i} & \text { downstream of the PBF }\end{cases}
$$

in which $s$ is the rate of fault displacement $(\mathrm{m} / \mathrm{kyr})$, linear over time. The age (in kyr, $A_{i} \cdot 10^{-3}$ ) was fed to the GSTAT program as a base function (cf. Pebesma and Wesseling, 1998). The displacement rate $(s)$ was least-square estimated simultaneously with the kriging calculations (i.e., universal kriging; cf. Pebesma and Wesseling, 1998; Burrough and McDonnell, 1998).

The Holocene-averaged displacement rate of the PBF was found to be $0.07 \pm 0.03 \mathrm{~m} / \mathrm{kyr}$, i.e., $0.44-1.10 \mathrm{~m}$ of vertical deformation (Table 3). Regional estimates, based on smaller subsets of index points, were also calculated, and are consistent with earlier local estimates (Table 3). They show that the averaged rate is based mainly on the middle Holocene densely sampled part (7.5$4.5 \mathrm{kyr} \mathrm{BP})$, and suggest a similar mean rate for 9.5-6.5 kyr BP. Fault activity could not be estimated for the late Holocene (5.5-2.5 $\mathrm{kyr} \mathrm{BP})$. For this time period, $s$ is predicted negative, with standard errors exceeding the estimates. The negative values imply that upstream of the PBF relative higher rates of groundwater rise occurred, in contrast to the early-middle Holocene situation of higher rates downstream. This does not suggest reversed activity of the fault zone, but reflects the late Holocene situation (see Introduction, see below) of excess fluvial sedimentation that causes upstream groundwater tables to rise, while downstream of the PBF groundwater tables remain at constant elevation. 
TABLE 3.-Differential subsidence rates across the PBF predicted by universal kriging (Equation 8)

\begin{tabular}{lcccccc}
\hline Time & Rate $\boldsymbol{s}$ & $\boldsymbol{\sigma}$ & $\boldsymbol{N}$ & Rate $\boldsymbol{s}$ & $\boldsymbol{\sigma}$ & $\boldsymbol{N}$ \\
{$[\mathrm{cal} \mathrm{kyr} \mathrm{BP}]$} & {$[\mathrm{m} / \mathrm{kyr}]$} & {$[\mathrm{m} / \mathrm{kyr}]$} & {$[-]$} & {$[\mathrm{m} / \mathrm{kyr}]$} & {$[\mathrm{m} / \mathrm{kyr}]$} & {$[-]$} \\
\hline \multicolumn{6}{c}{ Delta wide } \\
\hline
\end{tabular}

Entire delta (all points, Holocene-averaged)

$11.0-0.0$ cal kyr BP $\quad \mathbf{0 . 0 7} \quad \pm \mathbf{0 . 0 3} \quad \mathbf{3 1 3}$

North of delta axis (near $Z$ b) South of delta axis (near Dr)

Regional subsets (local neighborhood, radius: 1,500 yr, $23 \mathrm{~km} \mathrm{EW,} 16 \mathrm{~km} \mathrm{NS}$ )

$\begin{array}{lrrrrrr}5.5-2.5 \text { cal kyr BP } & -0.11 & \pm 0.14 & 18 & -0.08 & \pm 0.12 & 19 \\ 7.5-4.5 \text { cal kyr BP } & \mathbf{0 . 0 7} & \pm \mathbf{0 . 0 4} & \mathbf{6 0} & \mathbf{0 . 0 7} & \pm \mathbf{0 . 0 4} & \mathbf{5 6} \\ 9.5-6.5 \text { cal kyr BP } & \mathbf{0 . 0 8} & \pm \mathbf{0 . 0 4} & \mathbf{3 2} & \mathbf{0 . 0 7} & \pm \mathbf{0 . 0 4} & \mathbf{2 6}\end{array}$

Local scale (Cohen, 2003)

\begin{tabular}{|c|c|c|c|c|}
\hline $7.0-0 \mathrm{cal} \mathrm{kyr} \mathrm{BP}^{1}$ & $0.03-0.07$ & $4+46^{6}$ & & \\
\hline $7.0-5.5 \mathrm{cal} \mathrm{kyr} \mathrm{BP}^{2}$ & $>0.03-0.07$ & 20 & & \\
\hline $15-0 \mathrm{cal} \mathrm{kyr} \mathrm{BP}^{3}$ & $0.04-0.06^{5}$ & $135^{6}$ & $0.07-0.09^{5}$ & $145^{6}$ \\
\hline $15-8.0$ cal kyr BP v. later ${ }^{4}$ & & & $>0.07-0.09^{5}$ & $\sim 250^{6}$ \\
\hline
\end{tabular}

${ }^{1}$ Deformed floodbasin deposits incl. basal peat bed (EW $2 \mathrm{~km}$, NS $\left.1 \mathrm{~km}\right) ;{ }^{2}$ Divergence of groundwater rise curves $\mathrm{Zb}$ and $\mathrm{Bu}$ (6 km downstream of $\mathrm{Zb}$; Fig. 3D); ${ }^{3}$ Deformation of palaeovalley surface (length of $\mathrm{Zb}$ profile: $7.5 \mathrm{~km}$, length of Dr profile: $15 \mathrm{~km}$; lateral radius: 2-4 km). ${ }^{4}$ local divergence of Late-glacial and early Holocene buried channel belt surfaces ${ }^{5}$ Calculations cf. Cohen et al. (2002); ${ }^{6}$ boreholes reaching top of paleovalley surface.

\section{Other Local Controls}

In areas where groundwater discharge (seepage) occurs, groundwater levels as recorded by basal peat are locally higher (Berendsen, 1982; van de Plassche, 1982): Seepage in combination with peat formation may regionally raise groundwater tables above MSL. This clearly affected basal peat formation along the northern delta rim (Fig. 3B), where middle Holocene index points are higher than coeval samples in the central delta to the south (Fig. 3C). Furthermore, early Holocene podzolic paleosols occur directly below the basal peat of the northern delta rim, indicating that its formation was directly preceded by a considerable time of net infiltration. This implies that formation of basal peat regionally reflected landward migration of a seepage zone during the Holocene (de Vries, 1974). The source of this groundwater outflow is found in the ice-pushed ridges farther to the east (Fig. 7), which have been areas of net infiltration since their formation (Saalian, OIS 6, ca. 200-150 kyr BP). Deltaic sedimentation and peat formation forced by sea-level rise progressively sealed the sandy substrate, thereby altering the groundwater hydrologic situation and causing the migration of the seepage zone. It is hypothesized that the strongest increase in groundwater outflow occurred by the time that sea level had reached its highstand, ca. $6.0 \mathrm{kyr} \mathrm{BP}$, and that the most intensified outflow occurred in the area directly southwest of the ice-pushed ridges. In that area, outflow may have been further enhanced by PBF-displaced subsurface aquifers and aquitards. From water management of polders in that area, it is known that significant groundwater outflow occurs at present, and relatively high hydraulicheads are maintained naturally. Changes in groundwater hydrology (increasing seepage) may have had a local effect at sites near the icepushed ridge, not only along the northeastern delta rim but also at sites within the central delta, specifically sites $\mathrm{Zb}$ and Bu (Fig. 7). Most notably, after $6 \mathrm{kyr}$ BP a local bulge in paleo-groundwater tables appears superimposed on the regional gradient at these locations (Fig. 8). Despite the occurrence of this bulge directly downstream of the PBF, this bulge cannot originate from tectonic deformation: it domes upwards over time, whereas deformation would have warped it down. The bulge fades away in older groundwater levels and is absent in the $7.0 \mathrm{kyr} \mathrm{BP}$ paleo-groundwater table (Fig. 8). The question remains if it initially existed in older groundwater tables (implying that differential subsidence subsequently deformed it and caused it to fade away). Alternatively, it may have first originated at ca. $6.0 \mathrm{kyr} \mathrm{BP}$ and have been initially present in the local groundwater levels since. The latter explanation is favored because of the observed magnitude of the bulge relative to rates of differential subsidence. It explains the bulge in middle-late Holocene groundwater gradients as locally enhanced absolute rise of the water table (superimposed on the regional absolute rise caused by eustatic sea-level rise and fluvial discharge). In theory, palynological indicators in the basal peats may provide an independent check on changes in the balance between groundwater seepage and fluvial flooding as controls on floodbasin peat formation. However, at sites $\mathrm{Bu}$ and $\mathrm{Zb}$ an indistinctive mix of indicators for seepage and flooding was found in all samples. It is suggested that the bulge is the effect of 
increased groundwater outflow and that it reflects the present hydrologic situation of seepage from the nearby ice-pushed ridges, which evolved to this relatively enhanced state only by ca. 6.0 cal kyr BP, when sea-level rise was reaching its highstand and transgression ceased.

From earlier studies in the lower delta area, it is clear that tidal fluctuations are another control on groundwater levels (van de Plassche, 1982, 1995). Changes in floodbasin size and tidal inlets may have changed volumes of daily tidal currents (tidal prism). In the tidal floodbasin, basal peat may have formed at levels up to local mean high water (MHW), and changes in local MHW might be superimposed on the general sea-level rise (floodbasin effect; van de Plassche, 1982, 1995). Potentially, the interpolation technique may help to reconstruct paleo-floodbasin configurations. However, in this study tidal effects are not explored in detail.

\section{Aggradation Rates and Sedimentary Architecture}

The reconstruction of paleo-water-level rise in the floodbasins is linked to the sedimentary record of the fluvial channels (Fig. 9). The sedimentary architecture of the Rhine-Meuse delta has been described in a well-established space-time channel style model (Fig. 9A, B; Törnqvist, 1993; Makaske, 1998; Berendsen and Stouthamer, 2001). Törnqvist (1993) linked the longitudinal sedimentary architecture primarily to declining rates of relative sealevel rise; the interplay of upstream and downstream controls on fluvial style in the inland parts of the delta was assessed only qualitatively. This study explicitly quantifies groundwater-level rise within the coastal prism and allows to direct link sedimentation to regional floodbasin aggradation rates, at any location in the delta.

The highest rates of floodbasin aggradation occurred in the lower delta, between 9 and 4 cal kyr BP (Fig. 9C). This period is characterized by the occurrence of straight channels (cf. Makaske, 1998, 2001; anastomosing cf., Törnqvist, 1993). In the sea-levelcontrolled part of the delta, these channels started to form when aggradation rates exceeded $2.0 \mathrm{~m} / \mathrm{kyr}$. Because of the limiting effect of upstream controls, the channels formed up to 2 kyr later in the central delta, relative to the lower delta. The inland-most straight channels (active between 6 and 4 cal kyr BP) originated as partial avulsions (cf. Stouthamer, 2001; large-scale crevassing, cf. Makaske, 1998) of the Rhine trunk channel that flowed parallel to the northern delta rim. This trunk channel (Utrecht river system; cf. Berendsen, 1982; Berendsen and Stouthamer, 2001; Stouthamer, this volume, her fig. 5) was a meandering channel (Fig. 9B, location Ho, Wh). Locally higher subsurface erodibility (eolian coversands vs. clayey fluvial deposits) has been held responsible for the meandering style of channels in the delta rim area (e.g., Berendsen, 1982; Törnqvist, 1993). In addition, effects on bank stability by local groundwater outflow may have promoted a meandering channel style.

After 4 kyr BP, straight large-scale crevassing channels disappeared in favor of meandering channels (Fig. 9). This style change coincided with aggradation rates decreasing below $\sim 1.0 \mathrm{~m} / \mathrm{kyr}$. It also coincided with the occurrence of higher aggradation rates in the central-upper delta, relative to the lower delta. That indicates that aggradation rates had shifted from being dominantly downstream controlled to being upstream controlled, i.e., the interplay of upstream and downstream controls had changed. From the floodbasin aggradation rates (Fig. 9C) it appears that this shift had already set in earlier than indicated by the change in fluvial style (Fig. 9A): At 5 kyr BP, rates in the upper delta started increasing towards a maximum at $4 \mathrm{kyr} \mathrm{BP}$, when the eventual change in fluvial style in the central delta occurred. Meanwhile, aggradation rates in the lower delta decreased. The 5 to $4 \mathrm{kyr} \mathrm{BP}$ period coincided with the termination of global eustatic sea-level rise. Therefore the downstream expansion of meandering-river style may be the effect of a shift in relative importance towards upstream controls. However, the upstream control may have grown stronger in an absolute sense too. The observation that in the upper delta post-5 kyr BP aggradation rates did increase may point to the latter: that pattern in aggradation rates reflects increased discharge of water and / or sediment. Because basal peat indicators for paleoground water levels are not available for the period 2.5-0 kyr BP, no detailed interpretation of aggradation rates in the latest part of the Holocene was attempted. In related studies, the stable number of meandering channels, increasing channel width and meander wavelength after $3 \mathrm{kyr} \mathrm{BP}$, and increasing avulsion frequency since $4.7 \mathrm{kyr} \mathrm{BP}$ are seen as sedimentation increase reflecting increased discharge and/or sediment load (Stouthamer and Berendsen, 2000, 2001; Stouthamer, this volume). Both climate change and human impacts in the upstream drainage basin explain this increase, but separation of the human and climatic components in the upstream control remains a challenge. It is concluded that in the late Holocene (1) upstream controls grew in importance because relative sea-level rise had decreased and discharge increased, and (2) therefore fluvial sedimentation reached farther into the central delta than during the middle Holocene, resulting in highstand progradation.

\section{DISCUSSION}

\section{Coastal Prism Construction}

The interplay of downstream, upstream, and local controls identified for the Rhine-Meuse coastal prism has implications for the interpretation of coastal prism records in general. Commonly, coastal prisms are explained as a result of backfilling, driven by relative sea-level rise. This paper points out that to understand accommodation in a coastal prism it is important to break down relative sea-level rise into its component eustatic rise and ground subsidence. During the period of eustatic rise the Rhine-Meuse valley shows back-filling and extensive peat formation. In the paleo-valley, the point of Holocene onlap migrated upstream. In the period of decreased eustatic rise, peat formation eventually (by ca. 3 cal kyr BP) ceased. In both the central and the upper delta, aggradation continued after 3 cal kyr BP. In the central delta, this led to delta progradation, while upstream migration of the point of Holocene onlap continued. This implies that the river was still adapting its longitudinal profile, at a rate controlled by discharge and sediment load (upstream control) in the upper delta. This supports ideas on the Holocene onlap distance being influenced by hinterland sediment supply (e.g., Blum and Törnqvist, 2000, p. 19) but challenges the idea that the point of late Holocene onlap is a measure of the inland distance to which downstream controls reach.

\section{Backbarrier Delta as a Highstand Sediment Trap.-}

The central part of the coastal prism acted as a sediment trap, in particular after sea-level reached its highstand. The accommodation space created by eustatic rise was actively backfilled with peat, during rapid rise. After eustatic rise ceased, the fluviodeltaic system began prograding. Prograding fluvial deposits occurred on top of earlier accumulated peats. As these peats compacted, highstand sediment sank below the surface and was thereby trapped in earlier-provided (transgression-created) accommodation space (Fig. 10). A part from eustatic rise, subsidence also had created accommodation space during transgression (Fig. 10B, C) and continued to do so during progradation. In order to prograde 
Water-level rise at $t 0$, at river mouth

\section{Generalized longitudinal section} lower delta

central delta

upper delta

apex

\section{A) Solely eustatic rise}



time (millenia)

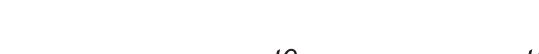

$t 1$

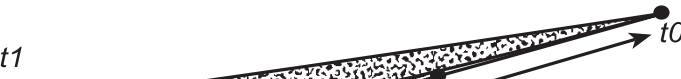

$t 1 \longrightarrow t 0$

$M S L$



ca. $5 \mathrm{~m}$

no tectonics (zero subsidence)

hinge zone

B) Long-term subsidence and eustatic rise

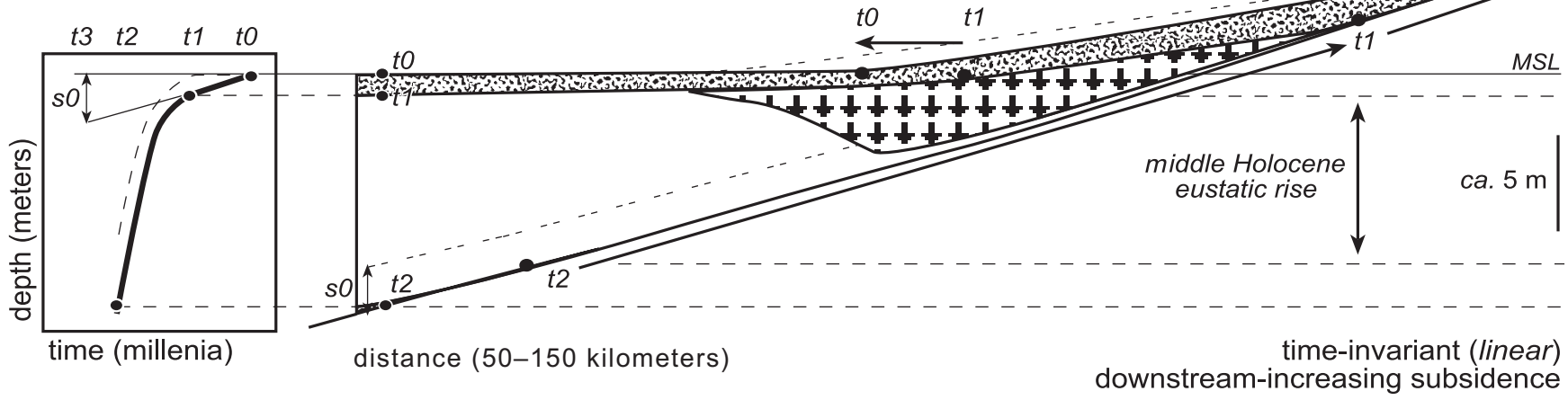

C) Post-glacial and long-term subsidence and eustatic rise

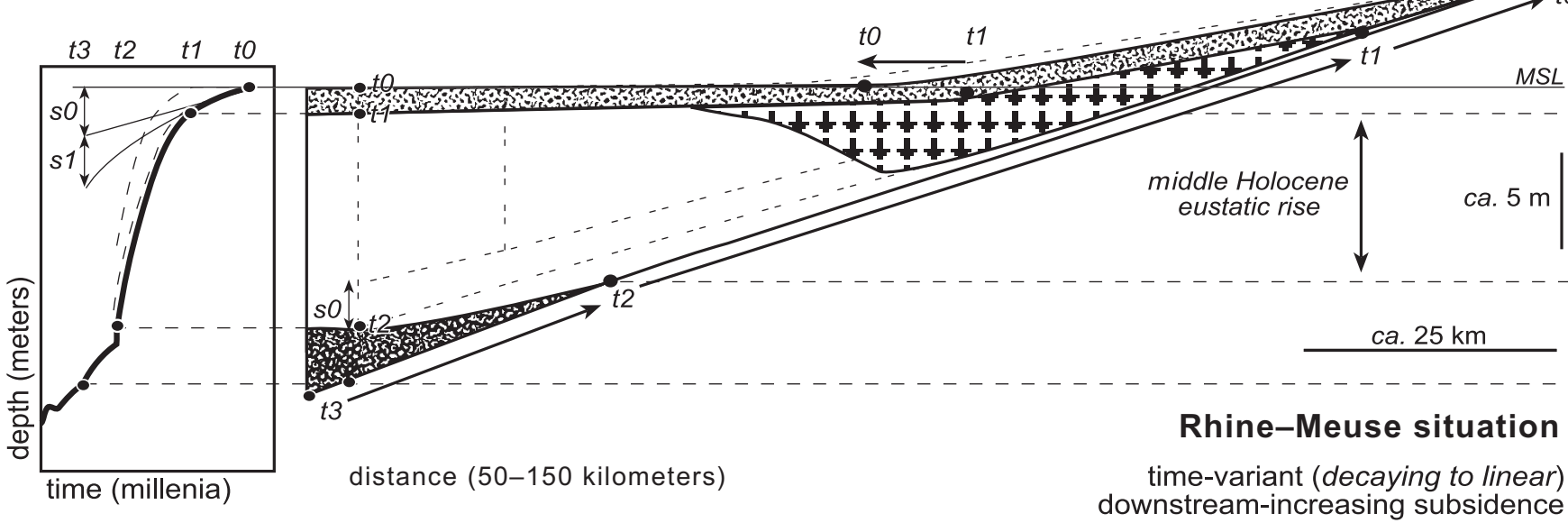

\section{Legend}

\begin{tabular}{ll} 
to & \\
t1 & late Holocene \\
t2 & middle Holocene \\
t3 & early Holocene \\
\hline & earliest Holocene
\end{tabular}

to present

$t 1$ end of eustatic rise

t2 onset directly sea-level-controlled aggradation

t3 End of rapid postglacial climatic amelioration

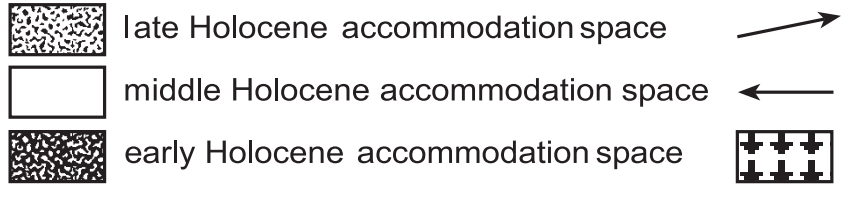

$\sqrt{ }$ Subsidence component

Relative water-level rise
Backfilling, inland migration of onlap

Progradation of fluvial delta

late Holocene accommodation of middle Holocene accommodation space 
(i.e., to raise its longitudinal profile), the river had to fill all these contributions to total accommodation space. If the highstand lasts long enough, continued sedimentation may eventually fill the lagoon completely, but in the central Rhine-Meuse delta ongoing accommodation so far has taken about 5,000 years since the highstand was reached and progradation of the delta into the backbarrier lagoon is still in progress. The tectonic setting seems to have amplified the efficiency of the central delta as a sediment trap, thereby counteracting progradation. Progradation in a nosubsidence situation would have been more rapid (Fig. 10). In the specific case of the Rhine-Meuse delta, differential subsidence related to the $\mathrm{PBF}$, which coincides with the central-upper delta transition, has further slowed down progradation.

During the middle and late Holocene, Rhine and Meuse avulsion locations clustered at the central-upper delta transition. The fact that avulsions concentrated at the upstream side of the central delta illustrates that this area was a sediment trap: repeated cycles of avulsion were needed for full accommodation. Repeated avulsion of distributaries is the mechanism that distributes fluvial sediments in the central delta. Nodal avulsion sites in the central delta may be a feature unique to rivers with a sediment load unable to fill the accommodation created within the period of activity of individual distributaries, as in the Rhine-Meuse delta. In contrast, a river with a larger sediment load would have filled the sediment trap of the central delta more rapidly, potentially without creating nodal avulsion sites within its delta. The reconstruction of paleo-groundwater rise for the Rhine-Meuse delta shows that gradients in the central delta have hardly changed over the last 6 kyr. This shows that besides repeated avulsion occurring at virtually the same locations, the area where fluvial gradients grade to sea level also remained at virtually the same

\section{$\leftarrow$}

FIG. 10 (opposite page)-Coastal-prism anatomy: eustatic rise and subsidence. Schematic diagrams showing subsequent contributions to accommodation space in a coastal prism. Upstream fluvial discharge and sediment load and initial paleovalley gradient are the same for all panels. Sediment load of the fluvial system is moderate, i.e., sufficient to fill accommodation space by creating a backbarrier delta that progrades into a lagoon but is insufficient to prograde beyond the transgressive coast line. A) No-subsidence situation: coastal-prism anatomy is regulated solely by the interplay of eustatic sea-level rise and upstream discharge and sediment load. In the late Holocene, new accommodation space is produced solely by fluvial sedimentation (upstream control). In addition to that, in the central delta accommodation of earlier provided accommodation space occurs, which reduces the efficiency of production of accommodation space by fluvial sedimentation. B) Linear subsidence component added. This subsidence facilitates a further downstream onset of coastal-prism aggradation. In the late Holocene, subsidence continues to produce accommodation space in the lower parts of the delta. This further reduces the efficiency of the production of accommodation space by fluvial sedimentation in the upper delta. C) Nonlinear subsidence component added. Early Holocene accommodation (of earlyHolocene-produced accommodation space) is preserved at the base of the coastal prism. Late Holocene accommodation is the same as in Part B. This panel represents the RhineMeuse case, except that contributions to accommodation by local controls (differential subsidence across fault zones, lateral groundwater flow; see text) are omitted from the graphs. location, some $30 \mathrm{~km}$ downstream of the avulsion nodes. Thus, the floodbasin groundwater-level record and the channel-belt sedimentary record of the Rhine-Meuse delta since the middle Holocene together reflect the sediment-trap effect of the central delta during a highstand.

\section{Early Holocene Part of the Coastal Prism.-}

The early Holocene record (before 8.2 kyr BP) of the RhineMeuse delta may be less comparable to other coastal prisms than its middle-late Holocene parts. Preservation of early Holocene sediments (Fig. 10C) is an uncommon feature; usually bases of coastal prisms date from after $8.2 \mathrm{kyr}$ BP (Stanley and Warne, 1994; situation illustrated in Fig. 10B). The Rhine-Meuse delta is uncommon because of the relative proximity to glaciations of the last glacial maximum (ca. $350 \mathrm{~km}$ away from the OIS 2 glaciation limits of the Scottish and Scandinavian ice sheets). This has had an imprint on the record of relative water-level rise (Kiden et al., 2002; Cohen, 2003) by enhanced subsidence related to deglaciation (hydro-isostasy and glacio-isostasy, forebulge collapse; e.g., Johnston, 1995). Particularly in the Late-glacial and early Holocene, higher rates of subsidence may have lowered the land surface and thereby promoted the transgression of the southern North Sea to occur earlier and farther inland than in a long-term subsidence-only situation. This may have caused groundwater rise and transformation of the paleo-valley into a fluvial delta relatively early, which explains observed early Holocene accommodation at the base of the present coastal prism (Fig. 10C). This feature probably is unique to coastal prisms in areas of former glaciation forebulges.

\section{Future Application: Interpolation vs. Process-Based Modeling}

A quantitative approach to Quaternary data is essential to link field results to models (Blum and Törnqvist, 2000; Paola, 2000). In calculating paleo-groundwater surfaces, reconstruction by interpolation is in fundamental contrast to reconstruction by process-based forward modeling of a paleo-situation. In a process-based modeling approach only antecedent data can be used in calculating subsequent groundwater levels. Additional physical processes (water flow) and boundary conditions (discharge, sea-level position, subsidence rates) need to be specified beforehand. In the reconstruction-by-interpolation approach, apart from conceptual pre-assumptions in the interpolation model (e.g., rise from lowstand to highstand), no information from outside the study area is introduced to calculate groundwater levels. The static preserved situation was interpolated instantaneously, on the basis of spatial and temporal correlations identified in the data. The resulting 3D block of data is in a format that allows direct validation of process-based model output, not just at the scale of individual sites of the input data, but also at delta-wide scale.

Three elements resulting from the interpolation design make the resulting reconstruction particularly applicable in processbased modeling studies. Firstly, because of the nature of the input data, the reconstruction results are averaged over geological time scales. Such results are more directly applicable as inputs in process-based models for geological time scales than modern-day instantaneous measurements in analogue systems, which inevitably need upscaling before they are applicable in geological process-based models. Secondly, the 3D interpolation can quantify differential subsidence and its tectonic deformations. This way present elevations of paleo-surfaces can be corrected to paleo-elevations (backstripping), which allows direct use of field data in model runs for paleo-scenarios. Lastly, 
the statistical error at each prediction location $\left(\sigma_{K}\right)$ is obtained and can be assessed explicitly in applications of the interpolation result.

By combining the reconstruction results with process-based models, the geological interpretations in terms of control interplay can potentially be strengthened further. For example, running a hydrodynamic model describing fluvial outflow into a lagoonal area may confirm the occurrence of reduced rates of inland groundwater-level rise. The hypothesis that locally higher aggradation in the northeast-central delta is an effect of shifts in groundwater outflow can be tested by running hydrological model scenarios for subsequent stages of delta buildup. Another future application of the interpolation is in process-based models of sedimentary architecture. With the delta-wide interpolation of floodbasin aggradation rates (Fig. 9) quantitative relations with delta-wide mapped channel-belt geometries can now be established. This is essential information to parameterize processes in models of sedimentary architecture. In particular, it is possible to assess the balance between regional aggradation rates (distal floodbasin aggradation) and local aggradation (proximal sedimentation, levee buildup), which is related to avulsion (e.g., Stouthamer, 2001; Törnqvist and Bridge, 2002; Stouthamer, this volume). In addition, model runs simulating the Rhine-Meuse delta can now be fed with realistic regional aggradation rates. In this way, the geological correlations between the channel record and the floodbasin record can be expanded to incorporate process-based, truly physical explanations.

\section{CONCLUSIONS}

This paper uses a geostatistical approach to perform an integrated analysis of late Quaternary sedimentary data from multiple sources. The dataset is exceptional in the resolution and quality of the data used, and in covering the complete evolution of a large Holocene coastal prism. Using geostatistical interpolation techniques, paleo-groundwater levels can be reconstructed and spatial and temporal trends in groundwater levels can be quantified. The geostatistical methodology puts field data into a form that allows direct use in process-based models because of the geologically averaged values, quantified errors, and quantified contemporary subsidence.

Trends that were observed over the entire Rhine-Meuse delta are attributed to the variable interplay of downstream and upstream controls (sea-level rise, absolute subsidence, changing discharge and sediment load); regional deviations are explained by local controls (differential subsidence related to fault zones, groundwater flow, tides). Relative rise is broken down into its components of eustatic rise and subsidence. The exact timing of the onset of aggradation and the exact rate of aggradation are a result of the complex interplay between sea level, upstream controls, and local controls. A dominant sea-level control on coastal-prism groundwater levels has been present since $8.2 \mathrm{cal}$ kyr BP, i.e., in the middle Holocene and late Holocene. From this time on, lagoonal areas with a near-zero gradient (lower-delta setting) existed inland from the present coastline. Quantified rates of groundwater rise show interplay with other controls (fluvial discharge, differential subsidence, groundwater hydrology), particularly in the area where rivers entered the lagoon (central delta).

The middle-late Holocene record of the central delta shows that groundwater gradients remained rather constant, despite changes in strength of downstream, upstream, and local controls. In the late Holocene, progradation of the central delta into the lagoon occurred, while backfilling continued upstream. As a result of continued subsidence and compaction of earlier peatfilled accommodation space, sediment of repeated avulsions was trapped in the central delta (Fig. 10). Such complex response may occur in other coastal prisms with backbarrier deltas. In the Rhine-Meuse delta, its effect was amplified by local differential subsidence. Holocene averaged rates of absolute subsidence appear 200-300\% larger than the average rate over a full glacial cycle. This subsidence provided accommodation space in the early Holocene. As a result, early Holocene fluviodeltaic deposits could fill this space and eventually remain preserved within the present highstand coastal prism. The latter may be a unique feature of coastal prisms in forebulge areas of the last glaciation.

\section{ACKNOWLEDGMENTS}

Numerous persons contributed in collecting, preparing, dating, documenting and verifying the 321 groundwater-level index points since the 1960s. Special thanks to M.H.M. van Ree for his contribution to sampling in the field and for selecting macrofossils for radio-carbon dating. For their participation in the field F.S. Busschers, M.J.P. Gouw, P.J. van Helvoort, J.P. Holten, P. van Santen, and C. Roosendaal are thanked. Dr. O. van de Plassche, and Dr. B. Makaske are thanked for sharing their latest datings in the near-coastal area (33 points). Special thanks to Dr. H.J.A. Berendsen, for discussions, reviews, editorial help, and compiling the archive of Rhine-Meuse delta radiocarbon datings (Berendsen and Stouthamer, 2000, 2001); to Dr. W.Z. Hoek for discussions and for providing his "LateglacialHolocene" palynological database used in the Appendix (Hoek, 1997b); and to Dr. E.J. Pebesma for discussions on how to apply geostatistics to geological groundwater rise and feedback on scripts and output of the GSTAT program (Pebesma, 1997). For their valuable comments Prof. Dr. E.A. Koster, Prof. Dr. Ir. M.F.P. Bierkens, Dr. T.E. Törnqvist, Dr. L.A. Tebbens, Dr. E. Stouthamer, Dr. C.R. Fielding, Dr. J.P. Bhattacharya, and L. Giosan are thanked. This research was part of a Ph.D. study 'Neotectonics in the Rhine-Meuse delta', sponsored by the Netherlands Organisation for Scientific Research (NWO) - Earth and Life Sciences (ALW). 


\section{APPENDIX: DATA-SET ENVELOPE, CONSTRUCTION OF BOUNDING SURFACES}

This appendix gives details on the construction of the bounding groundwater surfaces for the groundwater highstand and lowstand situation (Fig. 4B, D), based on data sets of contemporary topography (Fig. 4A, C) and regression approximations of the relation between the topographic surface and the groundwater table. Together the bounding surfaces form an envelope around the index points documenting the rise from lowstand to highstand during the Holocene. This envelope defines the local accumulated thickness $D$, which in the interpolation method is used to normalize the index-point data.

\section{Highstand Topography.-}

For the present highstand surface, digital elevation maps (DEMs) are available from geodetic surveys (Fig. 4A). However, the topography of The Netherlands is highly altered by humans, and over 2000 years of water management has resulted in a complex system of embanked floodbasins and peat excavations with groundwater levels maintained several meters below their original natural positions ("polders"). In the polders, groundwater levels are maintained at levels as low as 7 meters below MSL. Only a few topographic locations in the delta still represent natural highstand deltaic sedimentation levels, i.e., natural groundwater levels. The levees of sub-recently abandoned channels are among the locations where the surface still is at (or close to) its natural level. In a GIS (ArcInfo, ESRI 2000) a corrected digital elevation map of the present surface for its natural elevation (highstand digital elevation map; HDEM, Fig. 4B) was created. Actions involved masking all "polder" areas below present MSL and subsequently filling the masked areas by inverse distance interpolation with elevations along the levees of the sub-recent channels that fringe these polders (sampled by map overlay, using digital channel-belt maps of Berendsen and Stouthamer, 2001).

\section{Lowstand Topography.-}

For the lowstand surface, a digital elevation map was interpolated using the borehole database of Utrecht University (Berendsen et al., 1994; Berendsen and Stouthamer, 2001) and geological maps (for the westernmost part of the study area) of Geological Survey of The Netherlands (TNO-NITG). The digital elevation map for the late Pleistocene subsurface (Pleistocene digital elevation map: PDEM, Fig. 4C) was interpolated from aggregated point and contour data using the Topogrid algorithm as built-in in the GIS (ArcInfo, ESRI; Hutchinson, 1993).

\section{Relating Topography to Groundwater Level.-}

For the late Holocene highstand, the relation between local topographic elevation and groundwater level in the floodbasins is simple. The fresh, waterlogged state of the sediments in most of the delta, the generally immature soils (Histosols, Fluvisols, and Gleysols following FAO-Unesco classification; Driessen and Dudal, 1991), and extensive peat formation illustrate that the surface elevation is close to the regional ground water level, particularly in the floodbasins. Maturation of fresh sediments and autocompaction (cf. Allen, 1999) of peat lowers topography down to mean groundwater level, while dense vegetation (reed and sedges; Phragmites, Carex) produces peat and traps extra sediment, filling shallow lakes up to mean groundwater level (Fig. 2). Only close to distributary channels, natural levees are built up, which had mean groundwater levels below their surface. The digital elevation model of the late Holocene surface, therefore, directly represents groundwater level (HDEM, Fig. 4B). For the present Rhine-Meuse distributaries and the coastal barrier, the direct relationship between topography and groundwater level does not apply. The present channels have been embanked since approximately $1200 \mathrm{AD}$ and have silted up > 1 meter above their natural level (Middelkoop, 1997; Hesselink, 2002). The coastal barrier in the northwestern margin of the study area has eolian dunes on top; the groundwater level is meters below the dune tops (Fig. 1). In this area simple smoothing of the barrier elevation was performed. For the most seaward parts of the coastal barrier, the HDEM is relatively inaccurate but within acceptable limits for this study. For the embanked floodplains, the HDEM was corrected by lowering it by $1.5 \mathrm{~m}$ (maximum), to match the elevation in the direct surroundings of the embanked areas. The resulting HDEM (Fig. 4B) is representative of groundwater levels in distal floodbasins, the same setting where the basal-peat data come from.

For the lowstand situation, the relationship between the Late-glacial topography and early Holocene groundwater levels is less straightforward. However, the paleo-groundwater level could be calculated using palynological data that cover the Late-glacial to early Holocene transition in the Netherlands (Hoek, 1997a, 1997b, 2000; Bos, 1998; Wagner et al., 1999; Hoek and Bohncke, 2002). Sites located in topographic lows that contain organic-deposit fills were used, such as abandoned channels and brook valleys, and deflation lows and pingo remnants outside the Rhine-Meuse paleovalley. At various sites indications of a lowering of groundwater levels between 11.3 and 11.0 cal kyr BP (the "Rammelbeek" phase, cf. van Geel et al., 1981; "pollen subzone 4b", cf. Hoek, 1997a; Bos, 1998) are found in the palynological as well as in the lithological record (Hoek and Bohncke, 2002). Independent evidence indicates that meandering channels incised to a level below the Late-glacial floodplain, presumably in response to climatic amelioration during the earliest Holocene (Pons, 1957; Berendsen et al., 1995, Vandenberghe, 1995; Huisink, 1997; Tebbens et al., 1999). Combined geomorphologic and palynological evidence suggests (Hoek and Bohncke, 2002) that the lowering of the groundwater table between 11.3 and 11.0 cal $\mathrm{kyr} B \mathrm{P}$ was directly related to the fluvial incision. In this study, this is considered to be the last period of groundwaterlevel fall in the Rhine-Meuse paleovalley, after which regional groundwater rise started. Sedimentary and pedogenetic features in early Holocene fluvial deposits (e.g., organic horizons; Berendsen and Stouthamer, 2002) and the most downstream basal-peat datings (Fig. 3A) show that by $9.5 \mathrm{kyr} \mathrm{BP}$, at the present river mouth, groundwater had risen from its lowstand position to a level close to the Late-glacial floodplain surface. Hence, the $11.0 \mathrm{kyr} \mathrm{BP}$ groundwater level indicated by the palynological record is used as the lowstand groundwater surface in the groundwater reconstruction (Fig. 1).

The depths at which the $11.0 \mathrm{kyr}$ BP lowstand is recorded were queried from a palynological database (Hoek, 1997b; updated) and plotted (Fig. 11) versus the mean Late-glacial topographic elevation the direct surroundings of each locality sampled from the PDEM. In palynological records, the groundwater low stand was identified as a pollen subzone 4b ("psz.", cf. Hoek, 1997b), dated 




FIG. 11.-Local depth of 11.0 kyr BP "lowstand" groundwater table. The 11.0 cal kyr BP lowest Holocene groundwater level (as indicated by palynological records; Hoek 1997a, 1997b; Hoek and Bohncke, 2002) is below the Late-glacial surface. The regression analysis calculates the water-level depth below the average topographic elevation of its direct (500 $\mathrm{m} \times 500 \mathrm{~m}$ ) surroundings, as independently compiled in PDEM (Fig. 4). The regression intercept gives a relative depth of $1.7 \mathrm{~m}$. Within the study area, this relation is valid both for the partly buried paleovalley and for the partly buried surrounding delta rims ("coversands"). RVG = Roer Valley Graben.

to 11.3-11.0 kyr BP. The lowstand is recorded either as this pollen subzone within a continuous sequence covering the earliest Holocene completely (psz. 4a-4b-4c) or as an earliest Holocene oxidation event, i.e., a hiatus followed by an early Holocene pollen sequence (psz. 4c-5; latest Preboreal and Boreal stages: 11.0-ca. $10.0 \mathrm{kyr}$ BP; Hoek, 1997b). In the latter case, groundwater lowering itself (occurring between 11.6 and $11.0 \mathrm{kyr} \mathrm{BP}$ ) explains the hiatus: above it latest Late-glacial and earliest Holocene records were destroyed by oxidation, below it Late-glacial records are preserved un-oxidized. The groundwater level was set at the recorded depth of base of psz. 4c (i.e., either the level of the psz. 4b-4c transition or the level of the hiatus underlying psz. 4c). This gives a minimum elevation of the $11.0 \mathrm{kyr}$ BP lowstand level, because a palynological record would not have been preserved if the water tables had been lower. In continuous records, lithology (e.g., peat, clay, gyttja) and palynology (reed or woody vegetation) may indicate that paleo-water depths were above the level of palynological recording. Where the onset of psz. 4c is recorded in peat, the paleo-water depth was smallest (0-1.5 $\mathrm{m}$ for Phragmites peat, $0-0.5 \mathrm{~m}$ for woody peat). Hence, these points were used in quantitative analysis (Fig. 11).

Linear regression analysis related groundwater-table depth to surrounding topography (PDEM, Fig. 4C). The groundwater lowstand was $1.7 \mathrm{~m}$ (regression intercept) below averaged topographic elevation (Fig. 11). This result was used over the entire area, by performing the following GIS operations: (1) A first-approximation "groundwater lowstand" was interpolated (using the builtin Topogrid algorithm of the GIS; Hutchinson, 1993). For the area outside the paleovalley, modern topographic divides were used as "barriers" (cf. ESRI, 2000, Topogrid documentation) in the interpolation. (2) The relative depth of the lowstand groundwater table, below the topography (PDEM), was assessed: for cells with groundwater-depths greater than $1.7 \mathrm{~m}$, the depth of the groundwater table was set to $-1.7 \mathrm{~m}$ and raised by $10 \%$ of the excess difference, resulting in a groundwater table that smoothly mimics local relief. Such a procedure was needed because the first approximation is representative only for the direct surroundings of relatively low localities, such as those where fills formed and from which palynological records were available. (3) To minimize local effects inherited from irregularities in topography (PDEM), a 4-km-radius smoothing filter was applied to the lowstand groundwater surface (lowstand groundwater table digital elevation map LDEM; Fig. 4D). 


\section{REFERENCES}

ALLEN, J.R.L., 1999, Geological impacts on coastal wetland landscapes: some general effects of sediment auto-compaction in the Holocene of Northwest Europe: The Holocene, v. 9, p. 1-12.

BERENDSEN, H.J.A., 1982, De genese van het landschap in het zuiden van de provincie Utrecht: Ph.D. Dissertation, Utrecht University, Utrecht: Utrechtse Geografische Studies, v. 10, 256 p.

Berendsen, H.J.A., FAessen, E.L.J.H., AND KeMPEN, H.F.J., 1994, Zand in Banen: zanddiepte-attentiekaarten van het Gelders rivierengebied, Atlas, scale 1:25,000: Provincie Gelderland, Arnhem, the Netherlands, Digital maps.

Berendsen, H., HoEK, W., AND SCHORn, E., 1995, Late Weichselian and Holocene river channel changes of the rivers Rhine and Meuse in the Netherlands (Land van Maas en Waal), in Frenzel, B., ed., European River Activity and Climate Change During the Lateglacial and Holocene: European Science Foundation, project European Paläoklimaforschung, p. 151-172.

BERENDSEN, H.J.A., AND STOUTHAMER, E., 2000, Late Weichselian and Holocene palaeogeography of the Rhine-Meuse delta, The Netherlands: Palaeogeography, Palaeoclimatology, Palaeoecology, v. 161, p. 311-335.

BerendSen, H.J.A., AND Stouthamer, E., 2001, Palaeogeographical Development of the Rhine-Meuse Delta, The Netherlands: Assen, The Netherlands, Van Gorcum, 250 p. + digital maps.

Berendsen, H.J.A., And Stouthamer, E., 2002, Palaeogeographic evolution and avulsion history of the Rhine-Meuse delta, The Netherlands: Geologie en Mijnbouw / Netherlands Journal of Geosciences, v. 81, p. $97-112$.

Blum, M.D., AND TöRnQvist, T.E., 2000, Fluvial responses to climate and sea-level change: a review and look forward: Sedimentology, v. 47 (suppl. 1), p. 2-48.

Bos, J.A.A., 1998, Aspects of the Lateglacial-Early Holocene Vegetation Development in Western Europe. Palynological and Palaeobotanical Investigations in Brabant (The Netherlands) and Hessen (Germany): Ph.D. Dissertation, Utrecht University, Utrecht, Laboratory of Palaeobotany and Palynology Series, v. 10, p. 1-240.

Bronk-RAmsey, C., 1998, Probability and dating: Radiocarbon, v. 40, p. 461-474.

Burrough, P.A., AND McDonnell, R.A., 1998, Principles of Geographical Information Systems: Oxford, U.K., Oxford University Press, 333 p.

CoHen, K.M., 2003, Differential subsidence within a coastal prism. LateGlacial - Holocene tectonics in the Rhine-Meuse delta, The Netherlands: Ph.D. Dissertation, Utrecht University, Utrecht: Netherlands Geographical Studies, v. 316, 172 p.

Cohen, K.M., Stouthamer, E., AND Berendsen, H.J.A., 2002, Fluvial deposits as a record for neotectonic activity in the Rhine-Meuse delta, the Netherlands: Geologie en Mijnbouw / Netherlands Journal of Geosciences, v. 81, p. 389-405.

DE Groot, Th.A.M., AND DE GANS, W., 1996, Facies variations and sea-levelrise response in the lowermost Rhine-Meuse area during the last 15,000 years: The Netherlands, Geologische Dienst, Medelingen, v. 57 , p. 229-250.

DE VRIES, J.J., 1974, Groundwater flow systems and stream nets in the Netherlands: Ph.D. Dissertation, Vrije Universiteit Amsterdam, Amsterdam, $226 \mathrm{p}$.

Driessen, P.M., And Dudal, R., eds., 1991, The Major Soils of the World: Agricultural University Wageningen, Department of Soil Science and Geology / Katholieke Universiteit Leuven, Institute for Land \& Water Management, $310 \mathrm{p}$.

ESRI, 2000, ArcInfo 8.0.2: Environmental Systems Research Institute, Inc., Redlands, CA, U.S.A.

Hesselink, A.W., 2002, History makes a river. Morphological changes and human interference in the river Rhine, The Netherlands: Ph.D. Dissertation, Utrecht University, Utrecht: Netherlands Geographical Studies, v. 292, 177 p.
Hoek, W.Z., 1997a, Late-glacial and early Holocene climatic events and chronology of vegetation development in the Netherlands: Vegetation History and Archaeobotany, v. 1997 (6), p. 197-213.

HoEK, W.Z., 1997b, Atlas to Palaeogeography of Lateglacial Vegetations, Maps of Lateglacial and Early Holocene Landscape and Vegetation in The Netherlands, with an Extensive Review of Available Palynological Data: Netherlands Geographical Studies 231, 165 p.

Hoek, W.Z., 2000, Abiotic landscape and vegetation patterns in the Netherlands during the Weichselian Late Glacial: Geologie en Mijnbouw / Netherlands Journal of Geosciences, v. 79, p. 497-509.

HoEk, W.Z., AND BoHNCKE, S.J.P., 2002, Climatic and environmental events over the Last Termination, as recorded in The Netherlands: a review: Geologie en Mijnbouw / Netherlands Journal of Geosciences, v. 81, p. 123-137.

HOUTGAST, R.F., 2003, Quaternary tectonic and fluvial evolution of the Roer Valley Rift System, southern Netherlands: Ph.D. Dissertation, Vrije Universiteit Amsterdam, Amsterdam, 176 p.

Houtgast, R.F., van BaLEn, R.T., Kasse, C., AND VANDENBERGHe, J., 2003, Late Quaternary tectonic evolution and postseismic near surface fault displacements along the Geleen Fault (Feldbiss Fault Zone-Roer Valley Rift System, the Netherlands), based on trenching: Geologie en Mijnbouw / Netherlands Journal of Geosciences, v. 82, p. 177-196.

HuIsINK, M., 1997, Lateglacial sedimentological and morphological changes in a lowland river in response to climate change: the Maas, southern Netherlands: Journal of Quaternary Science, v. 12, p. 209-223.

Hutchinson, M.F., 1993, Development of a continent-wide DEM with applications to terrain and climate analysis, in Goodchild, M.F., Parks, B.O., and Steyaert, L.T., eds., Environmental Modeling with GIS: New York, Oxford University Press, p. 392-399.

JeLGERSMA, S., 1961, Holocene sea level changes in the Netherlands: Ph.D. Dissertation, Rijksuniversiteit Leiden, Leiden: Geologische Stichting, Mededelingen, Serie C-VI-no. 7, 101 p.

Johnston, P., 1995, The role of hydro-isostasy for Holocene sea-level changes in the British Isles: Marine Geology, v. 124, p. 61-70.

KIDEN, P., 1995, Holocene relative sea-level change and crustal movement in the southwestern Netherlands: Marine Geology, v. 124, p. 21-41.

Kiden, P., DenYs, L., AND JohnSTON, P., 2002, Late Quaternary sea-level change and isostatic and tectonic land movements along the BelgianDutch North Sea coast: geological data and model results: Journal of Quaternary Science, v. 17, p. 535-546.

MAKASKE, B., 1998, Anastomosing rivers-Forms, processes and sediments: Ph.D. Dissertation, Utrecht University, Utrecht: Netherlands Geographical Studies, v. 249, 287 p.

MAKASKE, B., 2001, Anastomosing rivers: a review of their classification, origin and sedimentary products: Earth-Science Reviews, v. 53, p. 149-196.

MiddelKoop, H., 1997, Embanked Floodplains in the Netherlands; Geomorphological evolution over various time scales: Ph.D. Dissertation, Utrecht University, Utrecht: Netherlands Geographical Studies, v. $224,352 \mathrm{p}$.

PaOla, C., 2000, Quantitative models of sedimentary basin filling: Sedimentology, v. 47 (suppl. 1), p. 121-178

Pebesma, E.J., 1997, Gstat User's Manual: Program manual (http:// www.gstat.org/).

Pebesma, E.J., And Wesseling, C.G., 1998, Gstat, a program for geostatistical modelling, prediction and simulation: Computers \& Geosciences, v. 24, p. 17-31.

Peltier, W.R., 2002, On eustatic sea level history: Last Glacial Maximum to Holocene: Quaternary Science Reviews, v. 21, p. 377-396.

Pons, L.J., 1957, De geologie, de bodemvorming en de waterstaatkundige ontwikkeling van het Land van Maas en Waal en een gedeelte van het Rijk van Nijmegen: Verslagen van Landbouwkundige Onderzoekingen, v. 63.11, 156 p.

Posamentier, H.W., Allen, H.W., James, D.P., and Tesson, M., 1992, Forced regressions in a sequence stratigraphic framework: con- 
cepts, examples, and sequence stratigraphic significance: American Association of Petroleum Geologists, Bulletin, v. 76, p. 1687-1709.

Stanley, D.J., AND Warne, A.G., 1994, Worldwide initiation of Holocene marine deltas by deceleration of sea-level rise: Science, v. 265, p. 228231.

STEENBEEK, R., 1990, On the balance between wet and dry. Vegetation horizon development and prehistoric occupation; a palaeecologicalmicromorphological study in the Dutch river area: Unpublished Ph.D. Dissertation, Vrije Universiteit Amsterdam, Amsterdam, 267 p.

STOUTHAMER, E., 2001, Holocene avulsions in the Rhine-Meuse delta, The Netherlands: Ph.D. Dissertation, Utrecht University, Utrecht: Nederlandse Geografische Studies, v. 283, 212 p.

Stouthamer, E., AND BerendSEn, H.J.A., 2000, Factors controlling the Holocene avulsion history of the Rhine-Meuse delta (The Netherlands): Journal of Sedimentary Research, v. 70, p. 1051-1064.

Stouthamer, E., And Berendsen, H.J.A., 2001, Avulsion frequency, avulsion duration and interavulsion period of Holocene channel belts in the Rhine-Meuse delta, The Netherlands: Journal of Sedimentary Research, v. 71, p. 588-597.

Stuiver, M., Reimer, P.J., Bard, E., Beck, J.W., Burr, G.S., Hughen, K.A., Kromer, B., McCormac, G., van der Plicht, J., AND Spurk, M., 1998, Intcal98 radiocarbon age calibration, 24,000-0 cal BP: Radiocarbon, v. 40, p. 1041-1063.

Tebbens, L.A., VeldKamp, A., Westerhoff, W., And Kroonenberg, S.B., 1999, Fluvial incision and channel downcutting as a response to Late-glacial and Early Holocene climate change: the lower reach of the River Meuse (Maas), the Netherlands: Journal of Quaternary Science, v. 14, p. 59-75.

TöRNQVIST, T.E., 1993, Holocene alternation of meandering and anastomosing fluvial systems in the Rhine-Meuse delta (central Netherlands) controlled by sea-level rise and subsoil erodibility: Journal of Sedimentary Petrology, v. 63, p. 683-693.

TÖRnQVist, T.E., VAN ReE, M.H.M., VAN ‘T VeER, R., AND VAN GeEL, B., 1998 , Improving methodology for high-resolution reconstruction of sea- level rise and neotectonics by paleoecological analysis and AMS ${ }^{14} \mathrm{C}$ dating of basal peats: Quaternary Research, v. 49, p. 72-85.

TöRNQvisT, T.E., AND BRIDGE, J.S., 2002, Spatial variation of overbank aggradation and its influence on avulsion frequency: Sedimentology, v. 49 , p. 891-905.

VANDENBERGHE, J., 1995, Timescales, climate and river development: Quaternary Science Reviews, v. 14, p. 631-638.

VAN DE Plassche, O., 1982, Sea-level change and water level movements in the Netherlands during the Holocene: Ph.D. Dissertation, Vrie Universiteit Amsterdam: Haarlem, The Netherlands, Rijks Geologische Dienst, Mededelingen, v. 36, p. 1-93.

VAN DE Plassche, O., 1995, Evolution of the intra-coastal tidal range in the Rhine-Meuse delta and Flevo Lagoon, 5700-3000 yrs cal B.C: Marine Geology, v. 124, p. 113-128.

VAN DE Plassche, O., AND RoeP, T.B., 1989, Sea-level changes in the Netherlands during the last 6500 years: basal peat vs. coastal barrier data, in Scott, D.B., Pirazzoli, D.B., and Honig, C.A., eds., Late Quaternary Sea-Level Correlation and Applications: NATO Scientific Affairs Commission, Dordrecht, The Netherlands, Kluwer Academic Publishers, p. 41-56.

van DijK, G.J., Berendsen, H.J.A., AND Roeleveld, W., 1991, Holocene water level development in The Netherlands' river area; implications for sea-level reconstruction: Geologie en Mijnbouw, v. 70, p. 311-326.

van Geel, B., BohnCKe, S.J.P., AND DeE, H., 1981, A palaeoecological study of an upper Lateglacial and Holocene sequence from 'De Borchert', The Netherlands: Review of Palaeobotany and Palynology, v. 31, p. 367-448.

VerbRAeCK, A., 1984, Toelichtingen bij de Geologische kaart van Nederland, schaal 1:50,000, bladen Tiel West (39W) en Tiel Oost (39O): Haarlem, The Netherlands, Rijks Geologische Dienst, 335 p.

Wagner, F., Bohncke, S.J.P., Dilcher, D.L., van Geel, B., AND Visscher, B., 1999, Century-scale shifts in Early Holocene atmospheric $\mathrm{CO}_{2}$ concentration: Science, v. 284, p. 1971-1973. 